\title{
An Ecohydrological Stream Type Classification of Intermittent and Ephemeral Streams in the Southwestern United States
}

Lainie Levick ${ }^{1}$, Samantha Hammer ${ }^{2}$, Russell Lyon ${ }^{2}$, Joel Murray ${ }^{3}$, Amy Birtwistle ${ }^{3}$, Dr. Phillip Guertin $^{1}$, Dr. David Goodrich ${ }^{4}$, Dr. Brian Bledsoe ${ }^{5}$, Dr. Melinda Laituri ${ }^{6}$

1'University of Arizona, Tucson, AZ 85721, llevick@email.arizona.edu, dguertin@cals.arizona.edu

${ }^{2}$ Former University of Arizona graduate students, Tucson, AZ 85721, sami.hammer@gmail.com, ralyon3@gmail.com

${ }^{3}$ Former Colorado State University graduate students, Fort Collins, CO 80523, jgjpmurray@yahoo.com, amy.birtwistle@gmail.com

${ }^{4}$ USDA-ARS/Southwest Watershed Research Center, 2000 E. Allen Road, Tucson, AZ 85719, dave.goodrich@ars.usda.gov

${ }^{5}$ University of Georgia, 507 Driftmier Engineering Center, Athens, GA 30602, bbledsoe@uga.edu

${ }^{6}$ Colorado State University, Fort Collins, CO 80523, melinda.laituri@colostate.edu

Corresponding author:

Lainie Levick

USDA/ARS Southwest Watershed Research Center

2000 E. Allen Road

Tucson, AZ 85719

llevick@email.arizona.edu

520-647-9153 


\begin{abstract}
An ecohydrological stream type classification was developed to improve decision making for ephemeral and intermittent streams at four military reservations in the southwestern U.S.: Fort Irwin, Yuma Proving Ground (YPG), Fort Huachuca, and Fort Bliss. Agglomerative hierarchical cluster analysis was used to classify stream reaches by ecohydrologic properties (vegetation, hydrologic, and geomorphic attributes derived using geographic information system analyses), and Classification and Regression Trees (CART) were used to determine thresholds for each variable for a predictive model. Final stream types were determined from statistical analyses, cluster validity tests, examination of mapped clusters, and site knowledge. Climate regime and geomorphology were most important for YPG and Fort Irwin where annual precipitation is low. Vegetation variables were important at Fort Bliss and hydrologic variables were important at Fort Huachuca where higher annual precipitation and a bimodal rainfall pattern occur. The classification results and input variables are spatially linked to specific stream reaches, allowing managers to identify locations with similar attributes to support management actions. These methods enable the development of a stream type classification in gauged or ungauged watersheds and for areas where intensive field data collection is not feasible.
\end{abstract}

\title{
Keywords
}

Military; arid land; stream classification; cluster analysis; classification trees

\section{Introduction}

The Department of Defense (DoD) manages over 35,600 km² (3.56 million ha) of arid and semiarid land in their Southwest Region (Figure 1) to meet its mission of providing national defense and to maintain its commitment to stewardship of its lands. The DoD recognizes the importance of maintaining the environmental quality and integrity of its installations for continued support and sustainment of training and testing exercises. This includes protection of natural resources and conservation of biological diversity through programs such as the Sustainment of Ranges and Operating Areas (DoD Directive 3200.15; Benton et al., 2008), and compliance with the Endangered Species Act to conserve the federally listed threatened and endangered species that occur on those lands (Rubinoff et al., 2006). Biological and habitat diversity is known to be considerably higher along ephemeral and intermittent stream corridors in comparison to adjacent uplands. Many of DoD’s largest training installations are located in the Southwest Region where ephemeral and intermittent streams are the predominant fluvial forms, yet knowledge of how these streams function and their effect on adjacent flora and fauna is limited. Understanding the hydrologic regime and related biotic features of these systems is an important task for management.

To provide an additional tool for DoD managers, an ecohydrologically-based stream type classification was developed for ephemeral and intermittent streams at four military reservations in the southwestern United States representing the four Level III ecoregions (Omernik and Griffith, 2014) that occur here: Fort Irwin National Training Center (Mojave Basin and Range), Yuma Proving Ground (YPG; Sonoran Basin and Range), Fort Huachuca (Madrean Archipelago), and Fort Bliss (Chihuahuan Desert) (Figure 1). Ecoregions provide a geographic framework for managing and understanding ecosystems by defining spatial units based on 
similar abiotic and biotic components (Omernik and Griffith, 2014). The stream types are based on vegetation, hydrologic, and geomorphic attributes derived from geographic information system (GIS) analyses and hydrologic modeling that can be used in defining ecohydrological relationships for management of wildlife habitat, including guiding wildlife surveys and monitoring, and other land management and planning actions. This paper presents the stream type classifications for the four installations and a comparison of the results. See Hammer (2014) and Levick et al. (2015) for the wildlife habitat and species associations using the stream type classifications and ecohydrological variables.

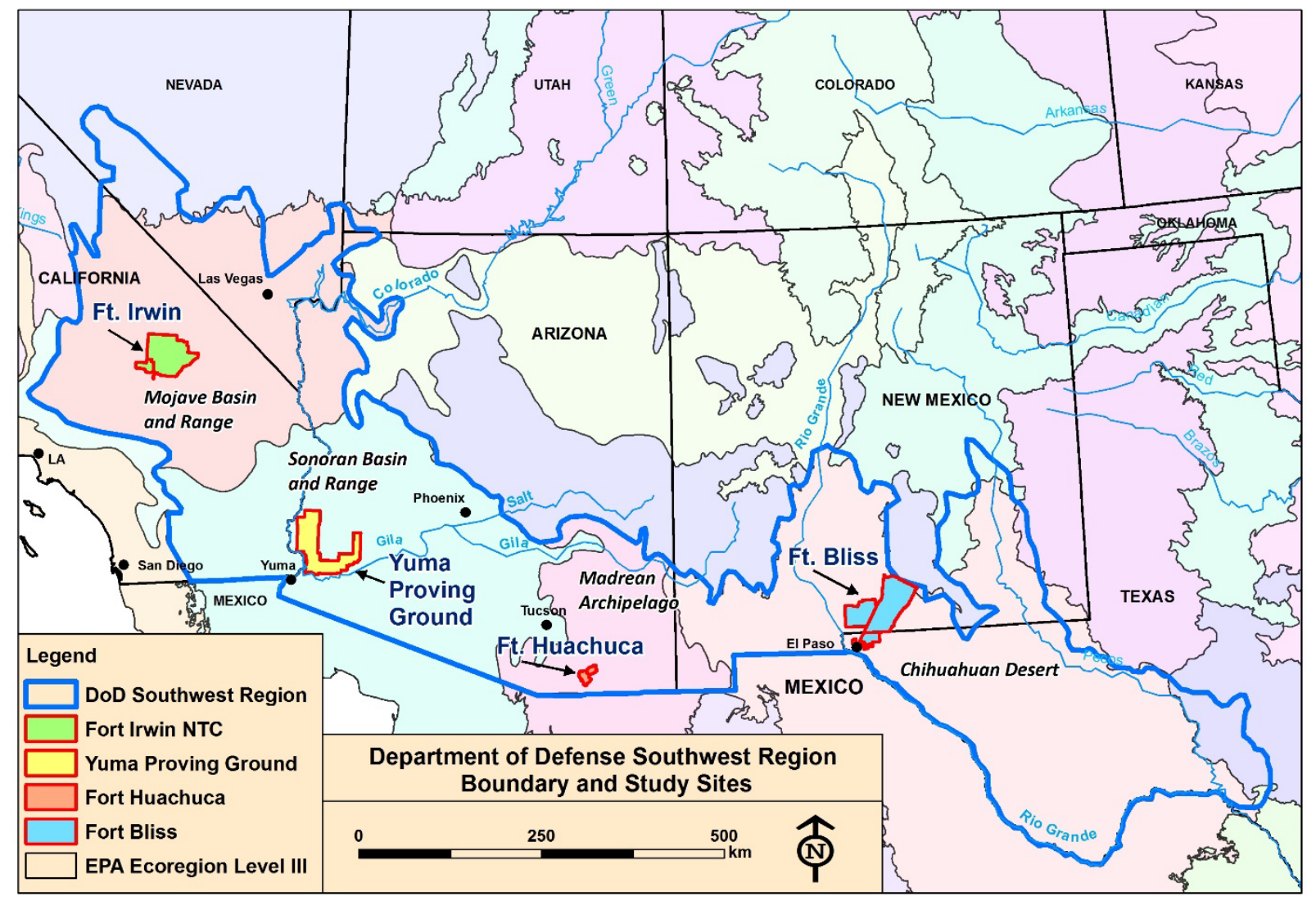

Figure 1. Map of the Department of Defense Southwest Region, ecoregions, and study locations: Fort Irwin National Training Center, Yuma Proving Ground, Fort Huachuca, and Fort Bliss.

\subsection{Study Sites Descriptions}

\subsubsection{Fort Irwin National Training Center, California $\left(2,590 \mathrm{~km}^{2}\right)$}

Fort Irwin is located in the Mojave Basin and Range ecoregion, just south of Death Valley National Park, and north of Barstow, California. Elevations range from 240 to 1,860 m. Terrain includes steep, rugged mountains, broad alluvial fans and bajadas, sandy plains, rolling hills, and playas. Fort Irwin receives approximately $110 \mathrm{~mm}$ (4.13 in.) of annual precipitation, with about half occurring during the winter as widespread, long duration events enhanced by El Niño conditions, and about $20 \%$ occurring during the summer. Rainfall is generally light, although thunderstorms can occur. 
There are no perennial surface flows at Fort Irwin; however, 14 (fourteen) springs are monitored regularly by Fort Irwin natural resources staff. Vegetation is shrub-dominated, with large areas of creosote-dominated alluvial fans and sandy, gently sloping surfaces, identified as SonoranMojave Creosotebush-White Bursage Desert Scrub. Riparian vegetation may be restricted to the channel banks, located only within the stream channel, or may not be present at all. Creosote frequently marks the division between the upland and channel, and is sometimes the upland vegetation identifier. Vegetation along the channel is frequently taller and denser than the same vegetation on the uplands. Listed threatened, endangered, and special status species include the threatened Desert tortoise (Gopherus agassizii), the federally listed endangered Land Mountain milkvetch (Astragalus jaegerianus), and federal species of concern Desert Cymopterus (Cymopterus deserticola). Military activities include training for heavy armor, mechanized infantry, Stryker, armored cavalry, and medium and light infantry units.

\subsubsection{Yuma Proving Ground, Arizona $\left(3,367 \mathrm{~km}^{2}\right)$}

Yuma Proving Ground is located in the Lower Colorado River Valley Subdivision of the Sonoran Basin and Range ecoregion, with elevations ranging from 54 to $868 \mathrm{~m}$. YPG receives about $92.7 \mathrm{~mm}$ (3.65 in.) of rainfall per year in a bi-modal pattern, with about one-third occurring as high-intensity, short-duration summer monsoon thunderstorms, and about 40\% occurring as gentle frontal systems during the winter months. There is no perennial surface flow; however, tinajas (natural rock water tanks) may be found in the mountains in various locations. Most of YPG is classified as Sonoran-Mojave Creosotebush-White Bursage Desert Scrub, and Sonoran Paloverde-Mixed Cacti Desert Scrub. Mesquite bosques occur in some areas. Riparian vegetation may be restricted to the channel banks, located only within the stream channel, or may not be present at all. Plants normally restricted to the uplands in wetter areas may only be found along the channels at YPG. Landforms include steep rugged mountains, alluvial fans, bajadas, sandy plains, sand dunes, and desert pavement covered piedmonts (fan terraces). While no threatened, endangered, or at-risk species are found here, twenty-two of Arizona's twentyeight protected bat species occur here, as well as large populations of desert bighorn sheep (Ovis canadensis nelsoni). Weapon systems and munitions tested at YPG include long-range artillery, missile firing aircraft cargo and personnel parachutes, direct fire weapons, unmanned aerial systems, and testing and evaluation of improvised explosive devices (IEDs).

\subsubsection{Fort Huachuca, Arizona $\left(291 \mathrm{~km}^{2}\right)$}

Fort Huachuca is situated on the eastern flanks of the Huachuca Mountains in southeastern Arizona, and ranges in elevation from about 1,220 to over $2,560 \mathrm{~m}$. It is located in the transition zone between the Sonoran Desert and Chihuahuan Desert, known as the Madrean Archipelago ecoregion. Fort Huachuca receives approximately $381 \mathrm{~mm}$ (15.6 in.) of annual precipitation in a bi-modal pattern, with nearly $60 \%$ occurring during the summer monsoon season, and about $25 \%$ falling during the winter. It is the only installation in this study with substantial permanent surface flow. Stream channels in the upper reaches of the Huachuca Mountains tend to be bedrock dominated or bedrock with alluvium, and is where most of the perennial flow occurs. The middle and lower stream reaches are generally incised alluvium and become wider and shallower with distance from the mountain front. Vegetation ranges from semi-desert mixed 
grasslands with mesquite, yucca and agave in the lower elevations, through Encinal pinyon-oak scrub and mixed deciduous in the middle elevations, to ponderosa pine forests in the higher elevations of the mountains. Riparian vegetation is present as sycamore, maple, and various shrubs in and along the upper stream channels, mixed with conifers, oaks, and juniper. The canopy in the upper channels is closed, with a well-defined structure of upper canopy, mid canopy, shrub, and ground cover layers. Riparian vegetation in the middle to lower elevations is generally denser, taller and more diverse than the adjacent uplands, and includes willow, mesquite, and grasses along the channel banks. There is a distinct change in slope and land cover at the base of the Huachuca Mountains, at just below 1,500 m elevation. Listed threatened, endangered, and at-risk species include the endangered Huachuca water umbel (Lilaeopsis schaffneriana var. recurva) and Southwestern willow flycatcher (Empidonax traillii extimus), and the threatened Chiricahua leopard frog (Rana chiricahuensis). Fort Huachuca is home to the Army Intelligence Center and School, the Army Network Enterprise Technology Command (NETCOM), the headquarters of Army Military Affiliate Radio System (MARS), the Joint Interoperability Test Command (JITC), and the Electronic Proving Ground (EPG).

\subsubsection{Fort Bliss, Texas/New Mexico $\left(4,530 \mathrm{~km}^{2}\right)$}

Fort Bliss is the largest of our study locations and the most challenging for stream type classification because of its large size and diversity of landforms. It is located in the Chihuahuan Desert ecoregion, with elevations ranging from approximately 1,170 to 2,700 $\mathrm{m}$. Fort Bliss receives approximately $220 \mathrm{~mm}$ (8.66 in.) of annual precipitation, over half of which falls during the summer months, with the remaining precipitation spread throughout the rest of the year. Rainfall can occur as intense localized downpours, creating large flashy runoff events. Dominant vegetation includes semi-desert grassland and steppe community, followed by stabilized coppice dune and sand flat scrub, creosote mixed desert scrub, and pinyon-juniper woodland in the mountains. The ecological management areas defined by the installation are (in order of largest area): Basin Aeolian, Basin Alluvial, Sacramento Mountains, Organ Mountains, Hueco Mountains, Otero Mesa, Franklin Mountains and Foothill-Bajada Complex. Over half of Fort Bliss falls under the Basin Aeolian management area that is mostly composed of stabilized coppice dunes that have no stream channel formation. The dunes are stabilized primarily with honey mesquite (Prosopis glandulosa) and four-wing saltbush (Atriplex canescens), but have little to no permanent vegetation between dunes. Otero Mesa is a large area of grasslands where the flow paths are visible as wide swales containing vegetation assemblages distinct from the adjacent uplands, generally graminoids with scattered shrubs. These areas are defined as sheetflood zones of discontinuous streams, or from NatureServe (NatureServe, 2014; http://www.natureserve.org) as Chihuahuan - Sonoran Desert Bottomland and Swale Grassland (Tobosa Swales). The remainder of Fort Bliss stream channels range from small incised channels to large arroyos and wide braided systems. Threatened, endangered, and at-risk species include the New Mexico Threatened Gray Vireo (Vireo vicinor), the federally endangered Northern aplomado falcon (Falco femoralis septentrionalis) and Sneed's Pincushion Cactus (Coryphantha sneedii var. sneedii). Fort Bliss is one of sixteen U.S. Army Training and Doctrine Command installations. Military activities include troop and equipment training, air defense and air-toground training, and ground maneuver training.

\section{Materials and Methods}


To produce the variables for the stream type classification, a unit of analysis was required, as well as delineation of a riparian zone for the vegetation attributes. We used one (1) kilometer $(\mathrm{km})$ as the unit of analysis based on our field experience as the average stream length that captures the overall variability along a stream, and all data were derived at that scale. Stream reaches were based on the USGS National Hydrography Plus Version 2 Dataset flowline (NHDPlus V2; USGS, 2006) for all natural water courses. Flowlines were split into +/- $1 \mathrm{~km}$ reaches using the ET GeoWizards tool (ET SpatialTechniques, http://www.ian-ko.com/). This tool splits a line into equal segments as close to the specified length as possible, adjusting the length to eliminate any remainders; therefore, not all stream reaches are exactly $1 \mathrm{~km}$ in length.

Delineation of the riparian zone was accomplished using the Hydro-Geomorphic Valley Classification Tool (HGVC; Carlson, 2009). This tool runs in ArcMap (ESRI, 2010), and inundates a DEM to a specified depth above the thalweg, creating a polygon that represents the water surface extent at that depth. To improve the accuracy of the analysis, the NHD flowline (used to inundate the DEM) was manually edited using hillshades and orthophotos to improve its location at the lowest part of the channel. This improved the accuracy of the vegetation variables and riparian widths derived from the resulting polygon. We used a LiDAR bare earth DEM or 10 m USGS DEM, depending on the installation, and inundation depths of $0.5 \mathrm{~m}, 2 \mathrm{~m}$, and $3 \mathrm{~m}$. The vegetation variables were derived using polygons for the $3 \mathrm{~m}$ inundation depth. This depth was selected using aerial imagery, field photographs, and field verification as the depth that resulted in the most accurate water surface extent to delineate vegetation most likely influenced by stream flow when it occurs (Figure 2). No attempt was made to include forbs and grasses resulting from seasonal rainfall or episodic stream flow since the goal was to identify the more permanent vegetation structure and abundance for use in wildlife habitat analyses. Riparian widths were derived from the $2 \mathrm{~m}$ inundated polygons and used in the stream type classification. The $3 \mathrm{~m}$ and $0.5 \mathrm{~m}$ widths were used to calculate the entrenchment ratio for the classification.
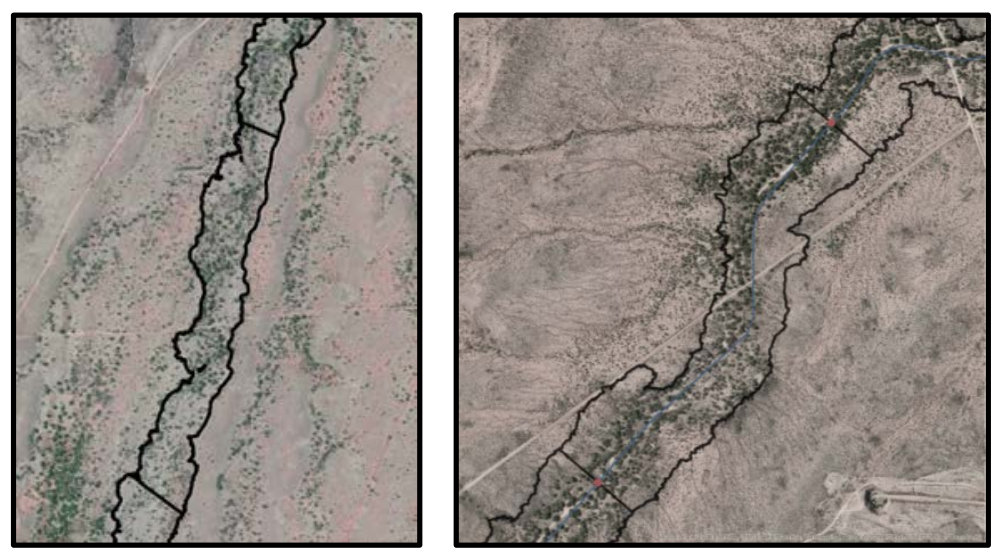

Figure 2. Images of the $1 \mathrm{~km}$ stream reach polygon representing water surface width at $3 \mathrm{~m}$ inundation depth, overlain on an orthophoto at Fort Huachuca.

Using the $3 \mathrm{~m}$ water surface extent for the analyses assumes that vegetation located more than 3 $m$ above the thalweg would not readily be able to access soil water associated with stream flow. Although various authors (see for example Cable, 1969; Canadell et al., 1996; Gibbens and Lenz, 
2001) have noted that root systems of many plants can extend much deeper than 3 m, many riparian associated plant roots are within the 1-3 m depth range.

\subsection{Variables for the Stream Type Classification}

Hydrologic, vegetation, and geomorphic variables used in the classification and for characterization of the stream reaches were derived for each $1 \mathrm{~km}$ stream reach and were georeferenced to each individual reach using a “Unique ID” in ArcMap (ESRI, 2010). All variables are listed below with a description of how it was derived.

\subsubsection{Hydrologic variables.}

2.1.1.1. The Automated Geospatial Watershed Assessment Tool (AGWA; https://tucson.ars.ag.gov/agwa), the Kinematic Runoff and Erosion Model (KINEROS2; Woolhiser et al., 1990; Goodrich et al., 2012), and the Soil and Water Assessment Tool (SWAT; Arnold et al., 1994) were used to derive two hydrologic variables: flow permanence and peak discharge. AGWA is a GISbased hydrologic analysis system for use by watershed, natural resource, land use managers, and scientists in performing watershed- and basin-scale studies (Miller et al., 2007; Goodrich et al., 2012; http://www.tucson.ars.ag.gov/agwa). AGWA parameterizes and runs the two hydrologic models, KINEROS2 and SWAT. Model results were transferred from the AGWA-generated streamlines to the NHD Plus V2 flowlines used for the stream network. The actual values for peak discharge and flow permanence are not intended to be used as absolute values since the models were not calibrated at each installation and were not used for predictive purposes. It is the range of values and where each stream reach falls in that range that is used to place it in a particular class. While results from these models are not used as absolute values in this classification, it is important to note the uncertainties and limitations of the models. Yatheendradas et al. (2008) identified rainfall estimates (depth/volume estimates and spatiotemporal resolution), model parameters, and initial soil moisture conditions as uncertainty sources in the KINEROS2 model. Hernandez et al. (2000) looked at both KINEROS2 and SWAT and found that the curve number, saturated hydraulic conductivity, and the spatial variability of rainfall, affected model performance. In most instances high-quality rainfall-runoff observations are not available for model calibration in these water limited ephemeral and intermittent streams. Using the AGWA/KINEROS2 model for relative assessments and rankings in data poor areas is discussed in Goodrich et al. (2012). A further discussion of the models and model uncertainties is included as Appendix B.

Flow Permanence (\%): Percent of the year there is flow in the channel, derived from the AGWA/SWAT model output for water yield (mm). SWAT is a curvenumber-based $(\mathrm{CN})$ model that uses hydrologic group, hydrologic condition, cover type, and antecedent moisture condition to calculate CN. Flow permanence was calculated as the number of days with flow above a certain cutoff value divided by the total number of days. Due to SWAT's inability to simulate zero flow conditions (Kirkby et al., 2011) it was necessary to establish cutoff values 
equivalent to zero to accurately describe flow permanence. The large variation in stream channel sizes necessitated that the cutoff values vary based on the contributing watershed area (Lyon, 2013). The correlation between flow permanence and watershed area at stream gauge and Tidbit sensor locations in Fort Huachuca was used to determine cutoff values. Tidbit sensors log temperature data from within the channel at 15-minute intervals and have been shown useful in detecting the onset and cessation of streamflow using a thermograph interpretation technique (Gungle, 2006). Data from two studies using Tidbit sensors were used: Gungle (2006), and Stromberg et al. (2015). Data from the Gungle (2006) study reported the timing and duration of flows over an 18-month time period in 2001-2002 from several locations in and around Fort Huachuca. The locations in Lower Garden and lower Huachuca Canyons on Fort Huachuca provided flow permanence observations for the low-lying alluvium dominated channels where more recent sensor data were unavailable. Additional Tidbit sensor data from Stromberg et al. (2015) provided data from 2011 that were used to assign the flow cutoff-watershed area classes for higher elevation, mountainous stream reaches. For each Tidbit sensor data location average annual flows were determined and compared to SWAT results. Flow presence cutoffs were increased in small increments until they were in close agreement with the observed data and used to define the different classes based on contributing watershed area. Watersheds with an area $<10 \mathrm{~km}^{2}$ were assigned a cutoff of $0.0001 \mathrm{~m}^{3} / \mathrm{sec}$; between $10-34.9 \mathrm{~km}^{2}$ a cutoff of $0.001 \mathrm{~m}^{3} / \mathrm{sec}$; and $>35 \mathrm{~km}^{2}$ a cutoff of $0.35 \mathrm{~m}^{3} / \mathrm{sec}$. Precipitation data used as input to the model were obtained from the Next-Generation Radar Multi-Sensor Precipitation Estimates (NEXRAD-MPE) from 2005-2012, obtained as a 4x4 km grid (one precipitation value per $16 \mathrm{~km}^{2}$ per day) from the NOAA Advanced Hydrologic Prediction Service for the conterminous United States (http://www.ncdc.noaa.gov/nexradinv/index.jsp).

Peak flow or discharge (Qp, $\mathrm{m}^{3} / \mathrm{s}$ ): Obtained from the AGWA/KINEROS2 model output for the 25-yr 1-hr design storm. Design storms for each installation were derived from the precipitation depths obtained from the pre-defined table of precipitation frequency estimates based on a specific return interval and duration from NOAA’s Precipitation Frequency Data Server (NOAA, 2012). The 25-yr 1hr peak flow was selected as the representative value for the wide range of conditions at these study sites, and relates to the range of channel-forming flows in this region (1-32 year return period; see Graf, 1988; Bull and Kirkby, 2002; Lopez-Bermudez et al., 2002; and Curtis et al., 2011), and is the minimum flow likely to inundate the overbank areas (Dust and Wohl, 2010).

2.1.1.2. Rainfall seasonality index (RSI): This index indicates the intensity of erosion potential due to precipitation characteristics, or the extent annual precipitation is concentrated in one month of the year, when larger flows that have more impact on channel geomorphology are more likely. It is derived from PRISM 30-year normals (PRISM Climate Group, 2010), for the 30-year period 1980-2010. It is 
calculated as the mean precipitation of the wettest month divided by the mean annual precipitation, at the mid-point of each stream reach (Eqn. 1).

$$
R S I=\frac{\text { Mean Monthly Precipitation of Wettest Month }}{\text { Mean Annual Precipitation }}
$$

This index is closely related to an extension of the Fournier Index, known as the Modified Fournier Index (MFI; Eqn. 2), which measures the effects of rainwater on erosion where higher values equate to more erosivity potential (Elagib, 2011). The RSI used in this analysis is a similar measure, where all values are unitless and less than 1.0.

$$
M F I=\sum_{n=1}^{12}\left(\frac{\left(\text { Monthly Precipitation }_{n}\right)^{2}}{\text { Annual Precip }}\right)
$$

\subsubsection{Vegetation variables}

2.1.2.1. Vegetation cover (\%): Derived from QuickBird (purchased from DigitalGlobe, Inc., https://www.digitalglobe.com/) or RapidEye (purchased from Spatial Energy, now part of DigitalGlobe, Inc., https://www.digitalglobe.com/) satellite imagery, using a vegetation index to classify the riparian zone into vegetation vs. bare ground or ground cover, with aerial photography and field photos as guides to verify vegetation pattern, density and cover (Figure 3). It is calculated as the total area of vegetation pixels determined from the vegetation index divided by the total area of the riparian zone (1 km stream reach polygon).

QuickBird satellite imagery, 2.4 m multispectral resolution, R-G-B-NIR bands (Fort Huachuca and Fort Irwin), used to derive the Modified Soil Adjusted Vegetation Index (MSAVI2; Qi et al., 1994; Eqn. 3).

$$
M S A V I 2=\frac{\left(2 * N I R+1-\sqrt{(2 * N I R+1)^{\wedge} 2-8 *(N I R-R E D)}\right.}{2}
$$

RapidEye satellite imagery, 5 m resolution, R-G-B-Red Edge-NIR bands (Fort Bliss and YPG), used to derive the Red Edge-NDVI vegetation index (Eqn. 4). RapidEye imagery was considerably less expensive than QuickBird imagery, and also included an additional band, the Red Edge band, that has been shown to improve vegetation analysis (Weichelt et al., 2012).

$$
R E N D V I=\frac{(N I R-R E)}{(N I R+R E)}
$$



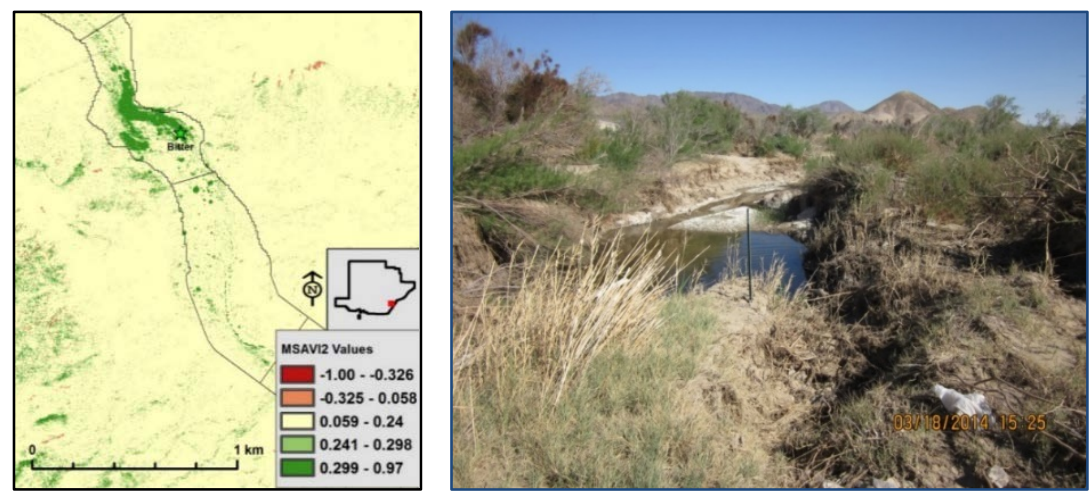

Figure 3. Map of Bitter Springs, Fort Irwin, showing MSAVI2 values (left; green pixels) used to determine vegetation cover vs. bare ground, and a photo of Bitter Springs (right). MSAVI2 values greater than 0.24 were classified as vegetation cover at Fort Irwin.

2.1.2.2. Mean Vegetation Index: Describes the relative vegetation density for each $1 \mathrm{~km}$ stream reach, calculated using only the pixels classified as vegetation cover from the satellite imagery to obtain the mean value (i.e., the pixels classified as bare ground or ground cover were not used to derive this variable). In areas of sparse vegetation, the vegetation index represents both vegetation and soil properties and can indicate the overall sparseness or density of the vegetation.

2.1.2.3. Vegetation structure (\%): Describes the vertical vegetation features derived from the multi-return LiDAR vegetation height layer (calculated by differencing the canopy or first return layer and the ground or last return layer) and classified into vegetation height categories based on typical vegetation structure (i.e., $<1 \mathrm{~m}, 1-4$ m, 4-12 m, >12 m; Stromberg, pers. com. 2010; Figure 4). Vegetation Structure represents the various areas of vegetation that wildlife typically use, and the percent cover of vegetation that is within that height layer. Note that these values do not account for vegetation that is beneath that height category (e.g., the 1-4 m high vegetation underneath the 4-12 m high vegetation), but represent only the vegetation within that height range. The lowest structure category was determined by selecting the vegetation height that best distinguished bare earth or ground cover from more permanent woody vegetation. This varied by installation as follows and was confirmed from field data and photos:

Fort Irwin: $0.5 \mathrm{~m}$ (small shrubs, sparse ground cover, small creosote, rocks) YPG: No LiDAR data available in time for this study Fort Huachuca: $1 \mathrm{~m}$ (extensive grass cover) Fort Bliss: $0.25 \mathrm{~m}$ (very small shrubs, ground cover and forbs) 


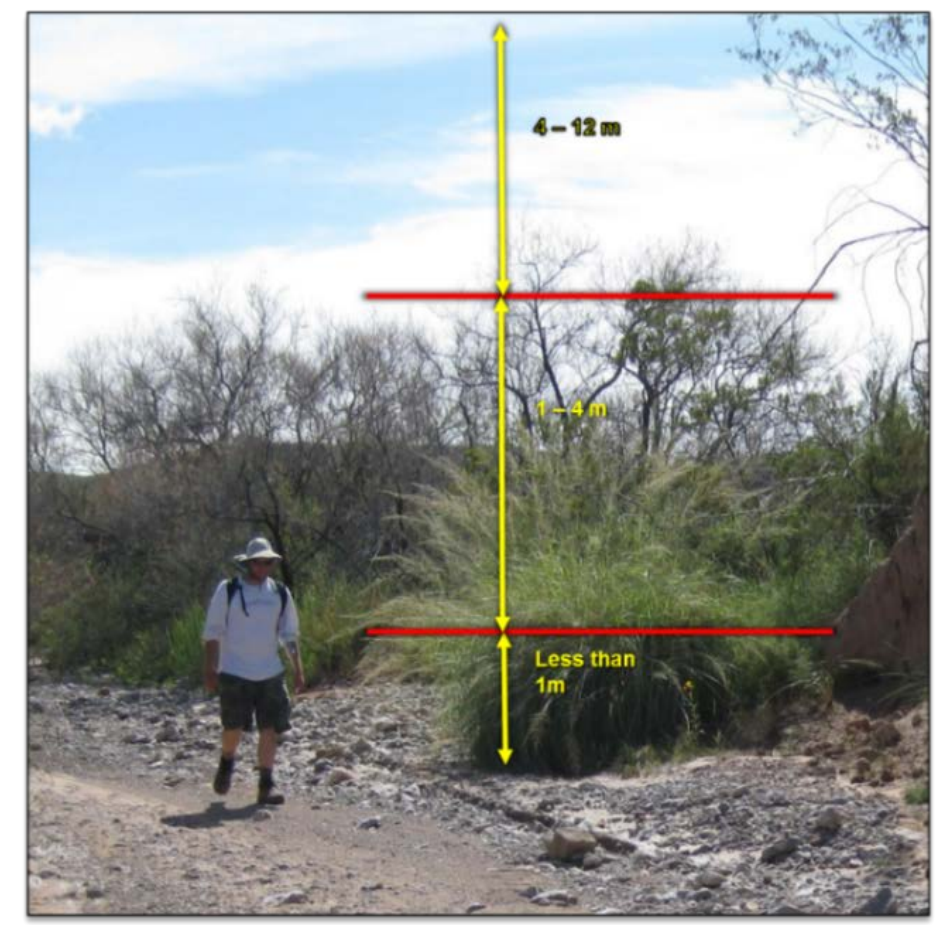

Figure 4. Photo illustrating vegetation structure layers.

2.1.2.4. Seasonal Vegetation Response Index (SVRI; percent change index): This variable was used to enhance the stream type classification for YPG in the absence of LiDAR vegetation structure data (LiDAR data were not available for YPG in time for this study). This index was only used at YPG. The SVRI was derived from a Landsat 5 TM analysis for vegetation seasonal response to monsoonal storms at YPG. Landsat 5 TM data were acquired for several dates bracketing the summer months from 2006 through 2010. Based on the National Weather Service monsoon statistics (http://www.wrh.noaa.gov/twc/monsoon/monsoon.php), 2008 was a wet monsoon for Yuma, Phoenix, and Tucson (37.8, 144.8, and $140.2 \mathrm{~mm}$, respectively), and would represent a year that would experience the greatest change in vegetation response between the beginning and the end of the summer months (June - September). The SVRI is calculated from the Landsat imagery using the mean vegetation index MSAVI2 value for each $1 \mathrm{~km}$ stream reach as a percent change index from June 11 to Oct. 1, 2008 (pre- to post-monsoon). The nonmetric multidimensional scaling (NMDS) analysis for YPG indicated that this variable was important in differentiating stream type clusters for that installation. For more information on our use of this index, see Levick et al. (2015).

2.1.3. Geomorphic and physical variables

2.1.3.1 Elevation (m): Derived from LiDAR bare earth DEM, or the $10 \mathrm{~m}$ USGS DEM for YPG, at the midpoint of each $1 \mathrm{~km}$ stream reach.

2.1.3.2. Slope (\%): Derived from the LiDAR bare earth DEM, or the $10 \mathrm{~m}$ USGS DEM for YPG, as the percent slope for each $1 \mathrm{~km}$ stream reach.

2.1.3.3. Total stream power $(\mathrm{kW} / \mathrm{m})$ : The rate of energy dissipation against the bed and banks of a channel; estimates the ability of the stream to transport sediment or 
cause erosion. Calculated using peak flow $\left(\mathrm{m}^{3} / \mathrm{s}\right)$ from the AGWA/KINEROS2 hydrologic modeling results for the 25-year return period storm and LiDAR or 10 m DEM for YPG derived slope (Eqn. 5).

\section{Stream Power $\Omega=\rho g Q S$}

where $\rho$ is the density of water $\left(1,000 \mathrm{~kg} / \mathrm{m}^{3}\right), g$ is acceleration due to gravity $(9.8$ $\left.\mathrm{m} / \mathrm{s}^{2}\right), Q$ is discharge $\left(\mathrm{m}^{3} / \mathrm{s}\right)$, and $S$ is channel slope (percent).

2.1.3.4. Cumulative area above the reach $\left(\mathrm{m}^{2}\right)$ : Represents the watershed area that contributes to stream flow at that reach, and is related to channel geometry and vegetation community differences; obtained from the AGWA model outputs.

2.1.3.5. Mean Riparian Width (m): Represents the mean distance from outside edge to outside edge of the riparian vegetation including the channel; calculated as the area of each $1 \mathrm{~km}$ stream reach polygon inundated to $2 \mathrm{~m}$ depth, divided by the actual length of the stream reach.

2.1.3.6. Entrenchment Ratio: A ratio indicating the degree of channel entrenchment or the vertical containment of the river; usually calculated as Flood Prone Width divided by Bankfull Width from field data (Rosgen, 1994), calculated here using mean riparian widths from the $3 \mathrm{~m}$ and $0.5 \mathrm{~m}$ inundation depths: (width at $3 \mathrm{~m} /$ width at $0.5 \mathrm{~m}$ ). Lower values (closer to 1 ) for the entrenchment ratio indicate higher entrenchment. This calculation assumes water surface width at $3 \mathrm{~m}$ inundation depth approximates Flood Prone Width, and water surface width at $0.5 \mathrm{~m}$ inundation depth approximates Bankfull Width

\subsection{Classification of Ephemeral and Intermittent Stream Types}

The stream type classifications for each installation were created using cluster analysis with all input variables. The analysis was performed in the $\mathrm{R}$ statistical package version 3.1.1 (R Core Team, 2014), using the hclust function for agglomerative hierarchical clustering, with the Euclidean distance function (ordinary distance), and Ward's method (minimizing total withincluster variance, centroid based, producing compact, spherical clusters, http://stat.ethz.ch/Rmanual/R-patched/library/stats/html/hclust.html). Each resulting cluster represents a stream type.

Nonmetric multidimensional scaling (NMDS) in R was used to view the structure of the datasets for each cluster result. The final number of clusters (stream types) for each installation was selected using cluster validity indices, examination of the mapped clusters, inspection of the resulting dendrograms from the agglomerative hierarchical clustering, the NMDS plots, and site knowledge. Over 30 cluster validity tests were performed in R, including silhouette widths, generalized minimum distance of distributions, dissimilarity measure, Dindex index, and Hubert index. These analyses produced either a plot or index that identified the optimum number of clusters by an abrupt change, bend or elbow in the data. The strongest tests were identified and selected based on Milligan and Cooper's (1985) review of procedures for determining the number of clusters in a data set.

The validity tests indicated that while there was usually one optimal cluster arrangement, there were several acceptable cluster configurations. Therefore, the results from the validity tests were 
used to guide the selection of the optimal number of clusters, but site knowledge, field data, photos, and examination of the mapped data were used to select the final arrangement that best described the variability across each installation. A one-way analysis of variance (ANOVA) and Tukey's Honestly Significant Difference (HSD) tests were used to determine if the variables within each cluster were statistically significantly different for each level of clustering. The tests compared the means and assigned a letter to each cluster that indicated its similarity to or difference from the other clusters. Clusters that do not share a letter have significantly different means. Boxplots were used to visualize the cluster statistics and identify the variables most important in defining each cluster. This information was also used in selecting the final number of clusters. See Levick et al. (2015) for the complete classification results, including the dendrograms, NMDS plots, and box plots for each installation.

A Classification and Regression Tree (CART; Breiman et al., 1984) analysis was used to identify the most important variables in defining the stream types, and to determine the thresholds or breaks for each variable for each stream type identified from the cluster analysis using the Salford Predictive Modeler software suite (Salford Systems, SPM, 2004). The final stream types from the cluster analyses were used as the target variables, and all defaults were kept for the initial tree (Gini method, 10-fold cross validation, no limits on tree size or minimum cases per terminal node, no weighting, and equal priors). The classification tree and thresholds can be used to predict stream types in stream reaches not included in the original analysis, and help in understanding how these systems function. Combining cluster analysis with decision trees has been described by various researchers as a data mining technique that improves accuracy and results (Aviad and Roy, 2011; Gothai and Balasubramanie, 2012; Sharma and Kaler, 2013). See Levick et al. (2015) for the decision trees for each installation.

\section{Results and Discussion.}

The results from this research are a GIS-based stream type classification with associated hydrologic, geomorphic, and vegetation variables, and a classification tree for all NHD Plus V2 stream reaches for each installation. Because the four installations have very different hydrologic regimes and geographic characteristics, each classification is unique and represents the variability of stream reaches within that installation. Fort Irwin, Fort Huachuca, and Fort Bliss all have eight final stream types, while YPG has ten stream types. These classifications can help identify stream reaches with similar characteristics, and can be used to guide management actions such as land development, land use, wildlife surveys, or sampling schemes, or to locate reaches with relatively high peak flows or flow permanence for transportation or other management actions.

We initially expected flow permanence to be a significant variable that would influence vegetation characteristics and the classification results overall. However, because flow permanence is generally low in these arid systems, except for a limited number of reaches at Fort Huachuca, it did not have a strong influence on stream type. The majority of stream reaches (62\%) analyzed in this study had flow permanence of less than $0.75 \%$ of the year (i.e., less than 3 days per year), with $89 \%$ having flow less than 3.32\% of the year (i.e., about 12 days per year). Maximum flow permanence was $92.53 \%$ at Fort Huachuca, but only $13.08 \%$ at Fort Irwin, $14.83 \%$ at YPG, and 33.53\% at Fort Bliss (Table 1). Fort Huachuca had the greatest range in 
flow permanence while Fort Irwin had the smallest range. Flow permanence values at Fort Huachuca ranged from less than $0.75 \%$ to over $80 \%$ for the 20 perennial stream reaches or about $8 \%$ of all reaches.

Although flow permanence was not one of the more significant variables in the classification, it can provide valuable insight into the nature of stream flow in these installations and desert regions. Streamflow permanence is a function of climate, topography, geology, soils, channel morphology, and the location of the stream reach within the watershed. In arid and semi-arid systems the timing and frequency of flow events can influence riparian vegetation and indicate the condition of the riparian system. Natural resource managers can use flow permanence data to evaluate the potential effect of different management scenarios on a stream reach. Both YPG and Fort Bliss have very few reaches with high flow permanence (highly skewed data, Table 1), and managers may be able to use these results to identify reaches with higher biological value requiring additional protection.

Table 1. Descriptive statistics for flow permanence (\%) at the installations

\begin{tabular}{|l|c|c|c|c|}
\hline & Fort Irwin & YPG & Fort Huachuca & Fort Bliss \\
\hline Mean & 2.04 & 0.16 & 21.96 & 2.34 \\
\hline Median & 1.06 & 0.07 & 10.89 & 1.20 \\
\hline Mode & 0.03 & 0.07 & 0.00 & 0.75 \\
\hline Standard Deviation & 2.34 & 0.83 & 26.98 & 4.32 \\
\hline Skewness & 1.49 & 12.47 & 1.20 & 4.58 \\
\hline Range & 13.08 & 14.83 & 92.53 & 33.53 \\
\hline Minimum & 0.00 & 0.00 & 0.00 & 0.00 \\
\hline Maximum & 13.08 & 14.83 & 92.53 & 33.53 \\
\hline no. of samples & 1427 & 2842 & 256 & 1994 \\
\hline
\end{tabular}

Each of the variables used in the classification can be evaluated individually for management purposes. Table 2 shows the relative importance (the "score") of each variable for each installation, as determined from the CART analysis of stream types. Scores are calculated for each variable in CART by determining its role as a splitter in that particular tree, and how much it improves the model. Stream types at Fort Huachuca, where annual precipitation is relatively high, were determined largely by the hydrologic variables (peak flow and rainfall seasonality index), while the geomorphic variables (elevation, slope, reach width, and watershed area) were more important at Fort Irwin, YPG and Fort Bliss where annual precipitation is lower. The Rainfall Seasonality Index (RSI) had a strong influence at Fort Huachuca, the location with the highest rainfall, and at YPG, the location with the lowest annual rainfall. The RSI is an index of the relative concentration of precipitation in one month, and these two locations experience the most pronounced bimodal rainfall patterns, suggesting the importance of this rainfall pattern in channel characteristics. Elevation and slope (and total stream power) were important at all installations because of the varied terrain and the strong influence of geomorphic factors on hydrologic and vegetative characteristics. Entrenchment ratio, a common geomorphic data type, was generally not very important in this analysis, possibly due to the method by which this variable was calculated or the application to ephemeral channels. 
The LiDAR-derived vegetation height variables and the satellite imagery-derived vegetation cover were most important in determining stream type at Fort Bliss, where vegetation type and structure are the most diverse. Fort Bliss is a large installation $\left(4,530 \mathrm{~km}^{2}\right)$ with grassland, shrubland, and woodland land cover types, resulting in a range of vegetation structures and communities. This was the only installation where all vegetation variables were among the most important. Stream reaches with higher cover or amounts of a particular height class can indicate potential habitat for wildlife species of concern.

In comparison, Fort Huachuca has the greatest annual rainfall which we expected would increase the importance of the vegetation variables; however, land cover is mostly grasslands and mesquite or scrub with little diversity in structure or species, except in the upper forested elevations. Due to the presence of monsoon storms and steep topography in the mountains, peak flow was the most important variable.

A discussion of the results for the stream types for each installation is included below. Tables that list the thresholds and percentages for each variable for each stream type in general order of importance are included in Appendix A. Values in the tables indicate the percent of stream reaches in each stream type for each variable range. The largest percentages are shown in bold font, indicating the majority of stream reaches. From these tables, the general characteristics of each stream type can be determined. The classification results and variables are spatially linked to specific stream reaches using a Unique ID, allowing managers to use the data to identify locations with specific attributes. 
Table 2. Variable importance (scores) at each installation, with annual precipitation totals.

\begin{tabular}{|c|c|c|c|c|c|c|c|}
\hline \multicolumn{2}{|l|}{ Fort Irwin } & \multicolumn{2}{|l|}{ YPG } & \multicolumn{2}{|l|}{ Fort Huachuca } & \multicolumn{2}{|l|}{ Fort Bliss } \\
\hline \multicolumn{2}{|l|}{$110 \mathrm{~mm}$ (4.13 in.) } & \multicolumn{2}{|l|}{$92.7 \mathrm{~mm}$ (3.65 in.) } & \multicolumn{2}{|l|}{$381 \mathrm{~mm}$ (15.6 in.) } & \multicolumn{2}{|l|}{$220 \mathrm{~mm}$ (8.66 in.) } \\
\hline Variable & Score* & Variable & Score* & Variable & Score* & Variable & Score* \\
\hline $\begin{array}{l}\text { Watershed Area } \\
\left(\mathrm{m}^{2}\right)\end{array}$ & 100.0 & $\begin{array}{l}\text { RSI - Rainfall } \\
\text { Seasonality Index }\end{array}$ & 100.0 & $\begin{array}{l}\text { Peak Flow 25-yr } \\
1-\mathrm{hr}\left(\mathrm{m}^{3} / \mathrm{s}\right)\end{array}$ & 100.0 & Veg $<0.5 \mathrm{~m}(\%)$ & 100.0 \\
\hline Elevation (m) & 95.9 & Width 2m (m) & 90.1 & Veg 4 - 12m (\%) & 64.4 & Elevation (m) & 90.4 \\
\hline Width 2m (m) & 92.8 & $\begin{array}{l}\text { Percent Slope } \\
\text { (\%) }\end{array}$ & 89.4 & $\begin{array}{l}\text { RSI - Rainfall } \\
\text { Seasonality Index }\end{array}$ & 55.4 & Veg 1 - 4m (\%) & 90.0 \\
\hline $\begin{array}{l}\text { Vegetation Cover } \\
(\%)\end{array}$ & 82.9 & $\begin{array}{l}\text { Watershed Area } \\
\left(\mathrm{m}^{2}\right)\end{array}$ & 78.9 & Elevation (m) & 51.2 & Width 2m (m) & 72.9 \\
\hline Percent Slope (\%) & 72.7 & $\begin{array}{l}\text { Total Stream } \\
\text { Power 25-yr 1-hr } \\
(\mathrm{kW} / \mathrm{m})\end{array}$ & 78.2 & $\begin{array}{l}\text { Total Stream } \\
\text { Power 25-yr 1-hr } \\
(\mathrm{kW} / \mathrm{m})\end{array}$ & 48.9 & Veg 4 - 12m (\%) & 69.9 \\
\hline Veg 0.25 - 1m (\%) & 55.6 & $\begin{array}{l}\text { Vegetation Cover } \\
(\%)\end{array}$ & 75.7 & $\begin{array}{l}\text { Watershed Area } \\
\left(\mathrm{m}^{2}\right)\end{array}$ & 48.1 & $\begin{array}{l}\text { Vegetation Cover } \\
(\%)\end{array}$ & 60.4 \\
\hline $\begin{array}{l}\text { Mean Vegetation } \\
\text { Index (MSAVI2) }\end{array}$ & 55.0 & $\begin{array}{l}\text { Peak Flow 25-yr } \\
1-h r\left(\mathrm{~m}^{3} / \mathrm{s}\right)\end{array}$ & 72.1 & Veg 0 - 1m (\%) & 45.9 & Veg 0.5 - 1m (\%) & 59.1 \\
\hline $\begin{array}{l}\text { RSI - Rainfall } \\
\text { Seasonality Index }\end{array}$ & 49.0 & Elevation (m) & 53.6 & $\begin{array}{l}\text { Entrenchment } \\
\text { Ratio (ER } \\
3 \mathrm{~m} / 0.5 \mathrm{~m})\end{array}$ & 39.4 & $\begin{array}{l}\text { Flow } \\
\text { Permanence (\%) }\end{array}$ & 56.1 \\
\hline $\begin{array}{l}\text { Total Stream } \\
\text { Power 25-yr 1-hr } \\
(\mathrm{kW} / \mathrm{m})\end{array}$ & 47.5 & $\begin{array}{l}\text { Flow } \\
\text { Permanence (\%) }\end{array}$ & 53.5 & $\begin{array}{l}\text { Mean Vegetation } \\
\text { Index (MSAVI2) }\end{array}$ & 39.4 & $\begin{array}{l}\text { Peak Flow 25-yr } \\
1-\mathrm{hr}\left(\mathrm{m}^{3} / \mathrm{s}\right)\end{array}$ & 56.1 \\
\hline $\begin{array}{l}\text { Flow Permanence } \\
(\%)\end{array}$ & 47.1 & $\begin{array}{l}\text { Mean Vegetation } \\
\text { Index (RENDVI) }\end{array}$ & 53.0 & Veg 1 - 4m (\%) & 38.9 & $\begin{array}{l}\text { Mean Vegetation } \\
\text { Index (RENDVI) }\end{array}$ & 52.4 \\
\hline Veg $0-0.25 \mathrm{~m}(\%)$ & 44.1 & $\begin{array}{l}\text { SVRI - Seasonal } \\
\text { Vegetation } \\
\text { Response Index }\end{array}$ & 47.5 & $\begin{array}{l}\text { Flow } \\
\text { Permanence (\%) }\end{array}$ & 35.2 & $\begin{array}{l}\text { Watershed Area } \\
\left(\mathrm{m}^{2}\right)\end{array}$ & 47.8 \\
\hline $\begin{array}{l}\text { Entrenchment } \\
\text { Ratio (ER } \\
3 \mathrm{~m} / 0.5 \mathrm{~m}) \\
\end{array}$ & 43.0 & $\begin{array}{l}\text { Entrenchment } \\
\text { Ratio (ER } \\
3 \mathrm{~m} / 0.5 \mathrm{~m})\end{array}$ & 21.2 & $\begin{array}{l}\text { Percent Slope } \\
(\%)\end{array}$ & 26.8 & $\begin{array}{l}\text { Percent Slope } \\
(\%)\end{array}$ & 31.8 \\
\hline Veg 1 - 4 m (\%) & 42.2 & & & Width 2m (m) & 21.0 & $\begin{array}{l}\text { Total Stream } \\
\text { Power 25-yr 1-hr } \\
(\mathrm{kW} / \mathrm{m})\end{array}$ & 28.7 \\
\hline $\begin{array}{l}\text { Peak Flow 25-yr } \\
1 \text {-hr }\left(\mathrm{m}^{3} / \mathrm{s}\right)\end{array}$ & 42.0 & & & Veg >12m (\%) & 17.6 & $\begin{array}{l}\text { RSI - Rainfall } \\
\text { Seasonality Index }\end{array}$ & 11.6 \\
\hline Veg 4 - 12m (\%) & 1.1 & & & $\begin{array}{l}\text { Vegetation Cover } \\
\text { (MSAVI2 \%) }\end{array}$ & 11.9 & $\begin{array}{l}\text { Entrenchment } \\
\text { Ratio (ER } \\
3 \mathrm{~m} / 0.5 \mathrm{~m})\end{array}$ & 7.2 \\
\hline
\end{tabular}

* Score indicates the relative importance of that variable in determining stream type at each installation. 


\subsection{Fort Irwin}

The cluster validity tests for Fort Irwin suggested five or twelve stream types as optimal. However, five stream types did not adequately describe the range of conditions and topographies found across the installation, and twelve clusters created several groups with very small differences based mainly on elevation. Eight stream types were selected using site knowledge in addition to the statistical tests to capture the variability that was not well differentiated using only the statistical methods (Figure 5).

Most stream reaches at Fort Irwin are characterized by low flow permanence (less than 3.94\% of the year), and low total stream power (TSP $<=1.28 \mathrm{~kW} / \mathrm{m}$ ) (Appendix A Table 1). Peak flows are also low, with a maximum of $61.8 \mathrm{~m}^{3} / \mathrm{s}$, and a mean of $0.7 \mathrm{~m}^{3} / \mathrm{s}$ for the $25-\mathrm{yr} 1-\mathrm{hr}$ event. Due to the low annual cool-season rainfall, low flow permanence, and small peak flows, vegetation tends to be sparse and small, making geomorphic factors more important in distinguishing stream types. Stream type 3 has the highest total stream power, with $81.5 \%$ of reaches having TSP $>1.28 \mathrm{~kW} / \mathrm{m}$, and are generally located in steeply sloped areas in hills or mountains. Stream type 6 is characterized as having the largest watershed area and relatively high flow permanence, but low elevation. These reaches are usually higher order streams located in the valleys. Stream type 7 has the widest reaches, and these reaches are located in the valleys where soils tend to be sandy or loamy sand. Stream reaches classified as stream type 8 are characterized by relatively high flow permanence and vegetation cover (>3.58\%), but are narrower with a smaller contributing watershed area than stream type 6 which also has high flow permanence and vegetation cover.

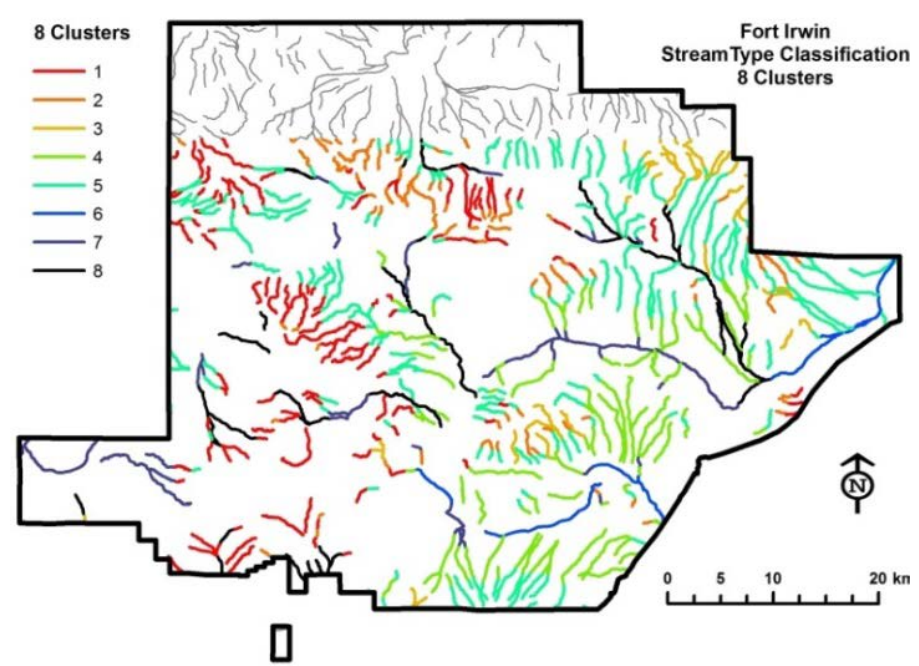

Figure 5. Fort Irwin map with eight stream types.

Note that LiDAR data were not available for the northern portion of Fort Irwin (gray stream lines); therefore the classification was not performed there.

\subsection{Yuma Proving Ground}

The cluster validity tests indicated that ten stream types were optimal at YPG, and this agreed with our knowledge of the installation and examination of the data and clustering results. YPG is our driest location, but experiences monsoon season storms which decrease towards the west. 
YPG wraps around the Kofa and Castle Dome Mountains, resulting in a large spatial extent with complex climate and geography. Rugged, igneous mountains and foothills, draining west towards the Colorado River, dominate the western arm of YPG. The eastern arm and southern region are alluvial, generally draining south towards the Gila River.

Geomorphic and climatic factors were the most important in determining stream types, with RSI, channel width, slope, and watershed area being the most important. Although flow permanence was not one of the most important variables in the CART analysis, it was the first splitter in the classification tree, separating out the small number of reaches with high flow permanence (stream type 3) from the rest of the stream reaches. Flow permanence is generally low $(14.8 \%$ maximum, $0.2 \%$ mean), but peak flows can be high with a maximum 25-yr 1-hr flow of 1,145.2 $\mathrm{m}^{3} / \mathrm{s}$ and a mean of $98.2 \mathrm{~m}^{3} / \mathrm{s}$, resulting in this variable being the second splitter in the CART tree.

The cluster analysis resulted in five main groups that were further split into 10 stream types. Nearly half of all stream reaches (47.9\%) were classified as stream types 1 or 2, located in the wide alluvial valleys (Figure 6). Stream type 6 is the next largest group, representing $13.5 \%$ of stream reaches, located in higher elevation areas.

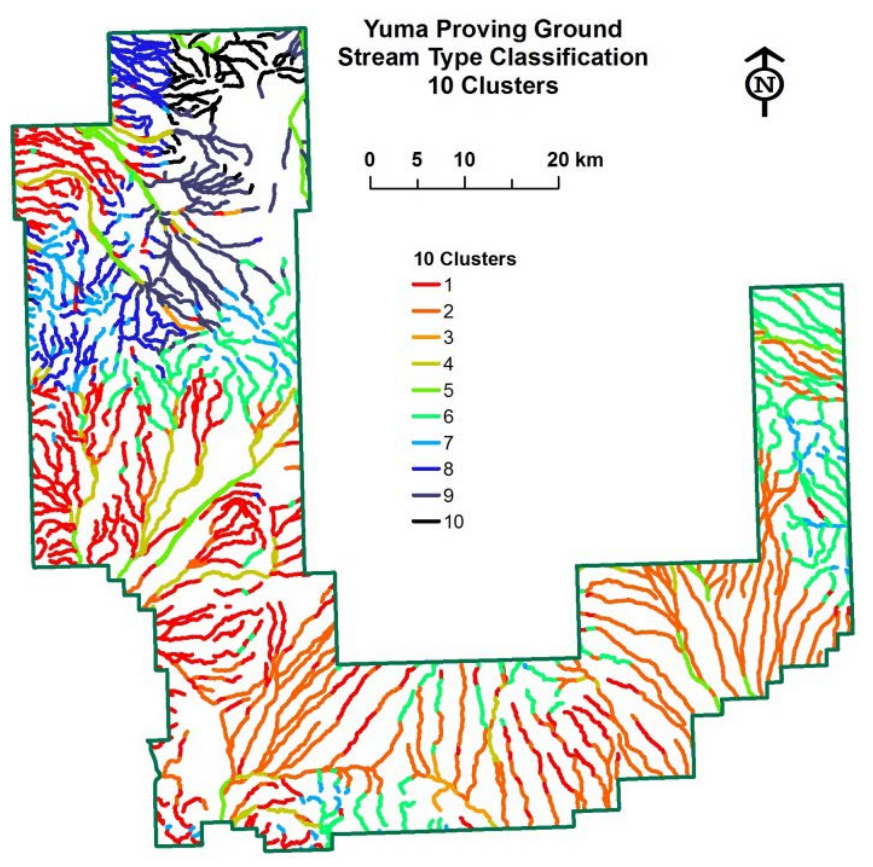

Figure 6. YPG map with ten stream types.

Because YPG has a great diversity of landforms, many of the variables have numerous thresholds (Appendix A Table 2), and frequently there is no single value representing the majority of stream reaches; however, the value representing the largest percentage of reaches is shown in a bold font in the table. Most stream types are generally characterized by low slope, low peak flow and low flow permanence, except for stream type 3 which has the highest mean flow permanence, and stream type 5 which has the highest mean peak flow and total stream power. Stream types 1 and 2 are characterized by low elevation, low slope, low vegetation cover and low SVRI (seasonal vegetation response index; developed for YPG because of the absence 
of LiDAR data). Both have a wide range of widths, although stream type 2 has the highest mean width, and stream type 1 has the lowest SVRI. Stream types 4 and 5 have the highest peak flows and total stream power of all stream types. Stream types 6 through 10 are the high elevation reaches, with stream types 7 and 10 having the greatest slopes of all stream types.

\subsection{Fort Huachuca}

The cluster validity tests indicated that five stream types exist at Fort Huachuca; however, based on site knowledge and the other statistical analyses we selected eight stream types. Although Fort Huachuca is a small installation, it has a wide range of elevation, slopes, vegetation communities, and flow permanence. Peak flow was high, with a maximum of $1,146.9 \mathrm{~m}^{3} / \mathrm{s}$ for the 25-yr 1-hr event, and an average of $137.2 \mathrm{~m}^{3} / \mathrm{s}$. Flow permanence is high compared to our other sites at $92.5 \%$ maximum and $22.0 \%$ mean. As expected due to the high annual precipitation, vegetation cover is high. Peak flow, vegetation at 4-12 $\mathrm{m}$ in height, RSI, elevation, and TSP were the most important variables in the CART analysis.

The stream types fell into four main groups that were further split into eight stream types, representing the high elevation mountains, mid elevation foothills, lower elevation grasslands, and the main-stem channel reaches (Appendix A Table 3). Stream types 1 and 2 constitute 18.3\% of stream reaches, all located in the upper elevation mountains. Stream types 3 and 4 represent $12.5 \%$ of stream reaches and are the main stem channels of the larger watersheds: Garden Canyon, Huachuca Canyon, Slaughterhouse Wash, and Rock Spring/Soldier Canyon. Lower Garden Canyon is separated to form stream type 3 due to its higher flow permanence, peak flows, entrenchment ratio, and vegetation cover and heights. It drains to the east to the San Pedro River unlike the other main stem channels that drain north to the Babocomari River.

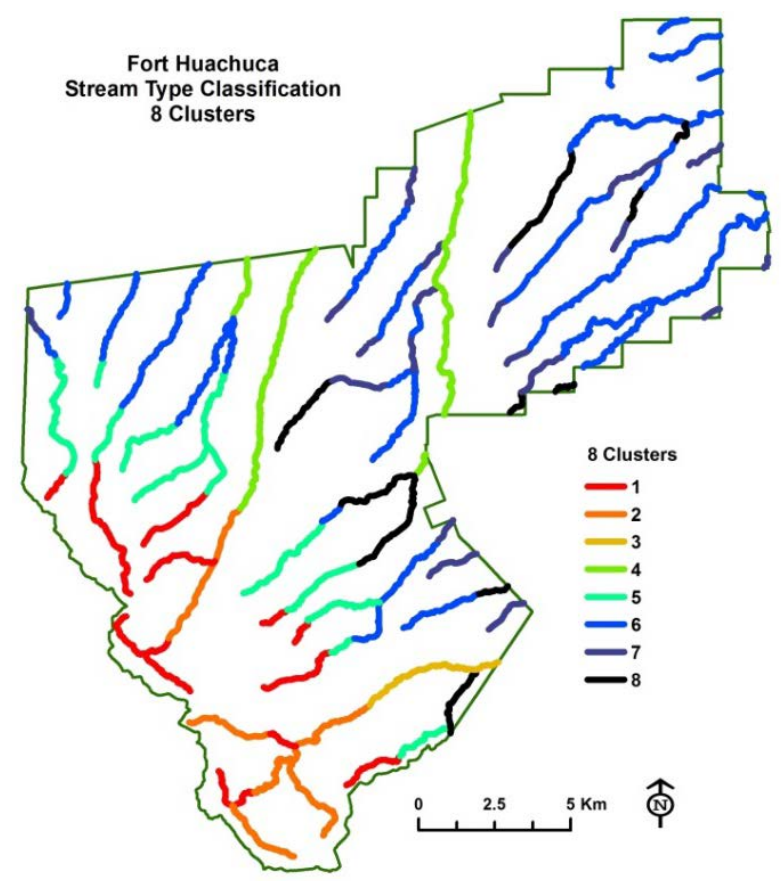

Figure 7. Fort Huachuca map with eight stream types. 
Stream types 1 and 2 are characterized by high percentages of vegetation taller than $4 \mathrm{~m}$, and high flow permanence, although stream type 1 has greater flow permanence than stream type 2 . Reaches in stream type 3 have high peak flow, the highest flow permanence, and a high entrenchment ratio. Stream type 5 represents the middle elevation foothill channels that transition from the mountains to the grasslands. Stream types 6, 7 and 8 have high amounts of vegetation below $1 \mathrm{~m}$, and very little above $4 \mathrm{~m}$ high, with relatively low peak flow, flow permanence and stream power. These reaches are located in the mesquite grasslands.

\subsection{Fort Bliss}

The cluster validity tests indicated that seven clusters were the optimum number for Fort Bliss. This cluster arrangement did not separate streams above and below Otero Mesa that, based on our field experience, have different characteristics. The next cluster level split those stream reaches, so we selected eight stream types for Fort Bliss.

The stream types fell into three main groups: high elevation - high slope mountain reaches, highelevation reaches, and lower elevation - low slope reaches (Figure 8). Stream types 1, 2 and 3 are higher elevation - high slope reaches, and represent $16.2 \%$ of all stream reaches. Stream types 4 , 5 and 6 , the second group of stream reaches, are high-elevation with moderate slopes and comprise $57.3 \%$ of reaches. Stream types 7 and 8, the lower elevation - low slope reaches, make up the remaining $26.4 \%$ of stream reaches.

Flow permanence is a maximum of 33.5\% in the upper reaches of the Organ Mountains, with an overall mean of $2.4 \%$. Stream type 3 has the greatest number of high flow permanence reaches, with $98.5 \%$ having a flow permanence of greater than $14.16 \%$, the highest flow permanence for Fort Bliss. Although stream flow is not common at Fort Bliss, flow permanence was the first splitter in the classification tree, indicating that stream reaches with high flow permanence have very different characteristics from other stream reaches. These reaches were generally higher elevation, with greater vegetation density and cover, and more vegetation over $12 \mathrm{~m}$ tall (Appendix A Table 4).

The vegetation variables were all important in this classification. In general, stream types 1, 2 and 3 have the greatest amount of vegetation cover, most of which is between $0.5-1 \mathrm{~m}$ in height. These three stream types also have the greatest amount of vegetation between $1-4 \mathrm{~m}$, and relatively higher slopes than the other stream types. Stream type 1 has $90.9 \%$ of reaches with more than $20.11 \%$ of vegetation between $1-4 \mathrm{~m}$ in height. Stream reaches in types 7 and 8 are the widest reaches, with the majority wider than $188.99 \mathrm{~m}$. Stream types 6,7 , and 8 are low elevation reaches. Peak flows can be very high with a maximum of $1,481.2 \mathrm{~m}^{3} / \mathrm{s}$ and a mean of $145.1 \mathrm{~m}^{3} / \mathrm{s}$ for the $25-\mathrm{yr} 1$-hr event. Stream type 8 has the highest peak flows of all stream reaches. 


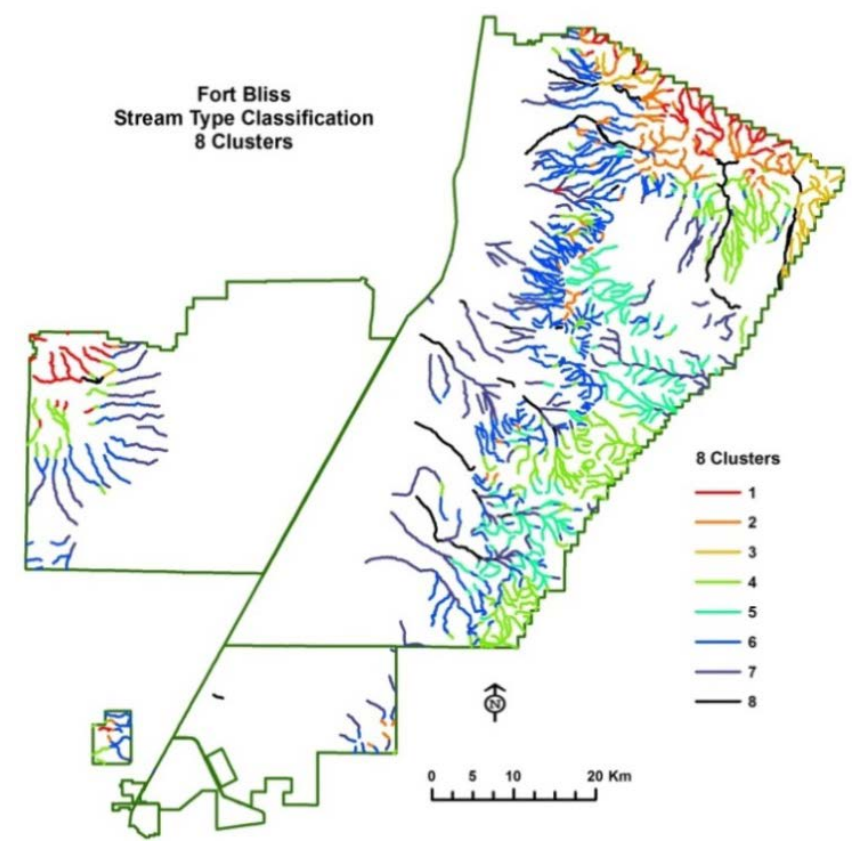

Figure 8. Fort Bliss map with eight stream types.

Fort Bliss has numerous discontinuous sheetflood reaches described as Chihuahuan-Sonoran Desert Bottomland and Swale Grassland (Tobosa Swales) by NatureServe (http://www.natureserve.org), and characterized by wide, shallow flow paths with vegetation distinct from the adjacent uplands. These reaches were not identified as a separate stream type using our methods; however, most of these reaches are classified as stream type 7 (widest and lowest slopes) or stream type 5 (lowest peak flow, low vegetation cover, and least amount of vegetation taller than $0.5 \mathrm{~m}$ in height). Many of these types of reaches may not have been included in the NHD stream network, due to how that network was created (note the large areas of Otero Mesa in the northeast area of the installation with no stream lines where many discontinuous reaches occur, Figure 8).

\section{Conclusions}

Classification schemes are becoming widely used as a tool to improve understanding and prediction of complex ecological data and patterns; however, these tools are best used as supplements to local ecological knowledge (Olden et al., 2008). Many studies classify streams based mainly on hydrologic metrics, using principal component analysis (McManamay et al., 2013; Oueslati et al., 2015), Bayesian mixture modelling (Kennard et al., 2010), or channel morphology (Rosgen, 1994; Montgomery and Buffington, 1997). In this study, a stream type classification based on hydrologic, vegetation and geomorphic attributes was developed for four military reservations in the southwestern United States using cluster analysis and CART. Detailed field data or streamflow gauge data are usually used in most classifications; however, due to the large geographic extent of this study and the lack of observed streamflow data, we utilized GIS-derived variables and hydrologic modeling results for our input metrics. These methods enable the development of a stream type classification in gauged or ungauged 
watersheds and for large areas where intensive field data collection is not feasible. Moving forward with landscape stratification and analysis is essential for advancing management of these resources and this methodology addresses a lack of gauge data that could hinder management actions. In general, the gauge network is especially sparse in arid regions, and this is a necessary approach.

An advantage of this methodology is that most of the variables used in these classifications are widely available or can be derived from hydrologic models run with nationally available meteorological and geospatial datasets. A limitation of applying this classification to other locations or installations is data availability, and the ability to perform the required analyses. However, Multi-return LiDAR data are becoming more available through the national USGS 3D Elevation Program (3DEP; https://nationalmap.gov/3DEP/).

The classification results and input variables are spatially linked to specific stream reaches using a Unique ID, allowing managers to use the data to identify locations with similar attributes to guide surveys for wildlife management, to develop sampling schemes or protocols, to locate reaches with relatively high peak flows or flow permanence for stormwater management, and to support other planning and management activities. The classification variables can be used singly or in combination to identify stream reaches with particular characteristics that may help determine suitable habitat for a particular species of wildlife or to perform a wildlife habitat analysis to determine the relative richness of different wildlife groups (mammals, birds, amphibians, reptiles, TER-S, etc.). The hydrologic variable for peak flow can be used to identify stream reaches with higher flood potential for use in planning future developments or training activities. The classification results can be used to gauge the ecological sensitivity of adjacent riparian areas and to guide land use activities away from more vulnerable environments.

The input variables were specific to each installation, and results were unique for each installation, as expected, highlighting the differences between the four installations and these desert regions. Variable importance in this water-limited region depended largely on the climate regime which influenced channel geomorphology and vegetation characteristics. Both the cluster analysis and the CART analysis outcomes suggested the importance of climate in determining the stream types. Geomorphology was most important at installations with low annual precipitation, while vegetation variables became more important as annual precipitation amount increased. The CART analysis of the stream types at each installation defined the range of the most important variables for each stream type, providing a method of placing a new stream reach into the classification. This predictive model is summarized in tables for each installation (Appendix A), where the percentage of stream reaches that fall within the thresholds (range of values) for each variable is shown for each stream type. The threshold that represents the largest percentage of reaches is highlighted using a bold font and is a good predictor for that stream type; when the percentages for all ranges are similar that variable is not a good predictor for that stream type.

Although YPG in the lower Sonoran Basin and Range ecoregion, and Fort Irwin in the Mojave Basin and Range ecoregion, both have low annual rainfall, they experience heavy seasonal thunderstorms that can produce high runoff and peak flows, which influence channel width and are related to watershed area. Those two variables were important in the classification outcomes 
for these arid locations. Limited rainfall leads to sparse vegetation with limited structural diversity, even along stream channels, and the variables related to vegetation had little influence in the stream type classifications for YPG and Fort Irwin. Stream types at those locations are primarily based on geomorphic factors. At Fort Bliss in the Chihuahuan Desert ecoregion, and Fort Huachuca in the Madrean Archipelago ecoregion, where higher annual rainfall is more evenly distributed throughout the year, the vegetation variables were more important. This is due to an increase in riparian structural diversity found at these more mesic sites. Fort Bliss typically receives over half of its annual rainfall during the summer monsoon growing season as convective thunderstorms, resulting in more vegetation along the channels. Fort Bliss has the highest simulated peak flows of the four installations, and intermediate flow permanence. Peak flow and the rainfall seasonality index were important at Fort Huachuca, which was expected due to the combination of intense summer monsoon thunderstorms and steep mountainous terrain. Fort Huachuca has the highest precipitation and flow permanence of the four installations.

The results indicate that changes in flow regime (peak flow and flow permanence) resulting from climate or anthropogenic change can modify channel and riparian structures. Both peak flow and flow permanence were important factors in the classification of channel types. At Fort Huachuca peak flow was ranked the most important factor for the stream type classification. A recent study at Fort Huachuca (O’Connor et al., 2016) predicted that potential changes in climate (i.e. increased temperature and precipitation primarily during the summer monsoon) would result in a small increase in flow permanence and a large increase in flood risk. The significant increase in flood risk is attributed to changes in vegetation types in the Huachuca Mountains, and increases in wildfire frequency result in longer periods of high flood risk. This may result in a shift to the high peak flow channel types 3 and 4 (Appendix A Table 4). The models developed in this study provide insight on the important factors governing channel and riparian conditions in the southwestern United States and how channel system mays adjust under changing conditions.

The methodology presented here attempts to advance the current knowledge of semiarid stream ecohydrology by examining how the hydrology (timing, frequency, and magnitude of streamflow events), vegetation, and geomorphology vary throughout different parts of a watershed. The stream type classifications and input variables provide an improved understanding of the ecohydrology of ephemeral and intermittent streams and the relationships between variables at each installation. This knowledge can be used to explore associations between hydrologic connectivity and sediment transport, vegetation communities, or wildlife species distribution, and can be useful where local data is not available or easily collected. A comprehensive, integrative approach to understanding stream dynamics in arid regions, as developed in this classification, is essential for future land and water planning as climate change accelerates.

The predictive models and classifications developed in this project are specific to the ecoregion in which they were developed, and should only be applied within the installation for which they were developed, or in the areas immediately surrounding that installation and within the same ecoregion. Misclassification errors (prediction success) generally occur where one stream type transitions to another or in stream types on the same branch of the dendrogram, indicating that those stream types are similar in many respects. Errors are likely due to heterogeneity of the 
input variables within the $1 \mathrm{~km}$ study reaches, which were determined graphically and not based on vegetation, geomorphic or hydrologic characteristics.

\section{Acknowledgements}

We greatly appreciated the opportunity to conduct this research, and thank John Hall, former Program Manager of the Department of Defense, Strategic Environmental Research and Development program (SERDP), Resource Conservation and Climate Change program area, his staff, and the staff at HydroGeoLogic for their funding, support, and guidance. We also acknowledge and thank the USDA-ARS Southwest Watershed Research Center, Tucson, AZ, for providing extensive in-kind support, including field vehicles for our many exciting excursions onto the installations. We thank the personnel at the Department of Public Works Environmental and the Range Operations personnel at Fort Bliss, Fort Huachuca, Fort Irwin and Yuma Proving Ground for their logistical and technical support, and for granting us access to their installations.

Funding: The funding for this research was provided by the Department of Defense, Strategic Environmental Research and Development program (SERDP), under the Resource Conservation and Climate Change program area, Project RC-1727. The USDA-ARS Southwest Watershed Research Center, Tucson, AZ, provided extensive in-kind support. 


\section{Appendix A. Tables}

The following tables list the thresholds and percentages for each variable for each stream type in general order of importance for where in the CART tree it split the data (i.e. For Fort Irwin, the first splitter was watershed area, followed by width, etc.). Values in the tables were derived from the CART analysis, and indicate the percent of stream reaches in each stream type for each variable range. The largest percentages are shown in bold font, indicating the majority of stream reaches. From these tables, the general characteristics of each stream type can be determined.

Appendix A Table 1. Fort Irwin thresholds for input variables and percent of each stream type for eight stream types.

\begin{tabular}{|c|c|c|c|c|c|c|c|c|c|c|}
\hline \multirow{2}{*}{$\begin{array}{c}\text { Stream } \\
\text { Type }\end{array}$} & \multicolumn{4}{|c|}{ Watershed Area $\left(\mathrm{m}^{2}\right)$} & \multicolumn{2}{|c|}{ Width $2 \mathrm{~m}(\mathrm{~m})$} & \multicolumn{2}{|c|}{ TSP 25-yr 1-hr (kW/m) } & \multicolumn{2}{|c|}{ ER $3 \mathrm{~m} / 0.5 \mathrm{~m}$} \\
\hline & $<=1,589,301$ & $<=327,136,256$ & $<=517,404,360$ & $>517,404,360$ & $<=228.02$ & $>228.02$ & $<=1.28$ & $>1.28$ & $<=4.78$ & $>4.78$ \\
\hline 1 & 17.2 & 82.8 & 0.0 & 0.0 & 100.0 & 0.0 & 100.0 & 0.0 & 44.1 & 55.9 \\
\hline 2 & 28.0 & 72.0 & 0.0 & 0.0 & 98.3 & 1.7 & 91.5 & 8.5 & 96.6 & 3.4 \\
\hline 3 & 4.9 & 95.1 & 0.0 & 0.0 & 98.8 & 1.2 & 18.5 & 81.5 & 70.4 & 29.6 \\
\hline 4 & 10.3 & 89.7 & 0.0 & 0.0 & 93.3 & 6.7 & 100.0 & 0.0 & 20.2 & 79.8 \\
\hline 5 & 13.6 & 86.4 & 0.0 & 0.0 & 95.9 & 4.1 & 96.3 & 3.7 & 28.6 & 71.4 \\
\hline 6 & 0.0 & 0.0 & 0.0 & 100.0 & 48.1 & 51.9 & 92.3 & 7.7 & 69.2 & 30.8 \\
\hline 7 & 2.8 & 97.2 & 0.0 & 0.0 & 5.5 & 94.5 & 100.0 & 0.0 & 97.2 & 2.8 \\
\hline 8 & 0.0 & 94.8 & 5.2 & 0.0 & 77.3 & 22.7 & 96.8 & 3.2 & 41.6 & 58.4 \\
\hline
\end{tabular}

\begin{tabular}{|c|c|c|c|c|c|c|c|c|c|}
\hline \multirow{2}{*}{$\begin{array}{c}\text { Stream } \\
\text { Type }\end{array}$} & \multicolumn{2}{|c|}{ Veg 0.25 - 1m (\%) } & \multicolumn{5}{|c|}{ Flow Permanence (\%) } & \multicolumn{2}{|c|}{ RSI } \\
\hline & $<=3.89$ & $>3.89$ & $<=3.94$ & $<=4.74$ & $<=6.95$ & $<=7.00$ & $>7.00$ & $<=0.20$ & $>0.20$ \\
\hline 1 & 95.2 & 4.8 & 98.7 & 1.3 & 0.0 & 0.0 & 0.0 & 0.0 & 100.0 \\
\hline 2 & 16.1 & 83.9 & 92.4 & 0.8 & 3.4 & 0.0 & 3.4 & 0.0 & 100.0 \\
\hline 3 & 66.7 & 33.3 & 91.4 & 0.0 & 8.6 & 0.0 & 0.0 & 48.1 & 51.9 \\
\hline 4 & 100.0 & 0.0 & 96.8 & 2.8 & 0.4 & 0.0 & 0.0 & 0.0 & 100.0 \\
\hline 5 & 96.3 & 3.7 & 96.1 & 3.2 & 0.7 & 0.0 & 0.0 & 5.3 & 94.7 \\
\hline 6 & 98.1 & 1.9 & 0.0 & 23.1 & 76.9 & 0.0 & 0.0 & 0.0 & 100.0 \\
\hline 7 & 100.0 & 0.0 & 58.7 & 5.5 & 31.2 & 1.8 & 2.8 & 0.0 & 100.0 \\
\hline 8 & 99.4 & 0.6 & 2.6 & 13.0 & 37.7 & 3.9 & 42.9 & 0.0 & 100.0 \\
\hline
\end{tabular}

\begin{tabular}{|c|c|c|c|c|c|c|c|c|c|c|}
\hline \multirow{2}{*}{$\begin{array}{c}\text { Stream } \\
\text { Type }\end{array}$} & \multicolumn{3}{|c|}{ Elevation (m) } & \multicolumn{3}{|c|}{ MSAVI2 Mean } & \multicolumn{2}{|c|}{ Vegetation Cover (\%) } & \multicolumn{2}{|c|}{ Veg 1 - 4m (\%) } \\
\hline & $<=838.69$ & $<=897.65$ & $>897.65$ & $<=0.24$ & $<=0.29$ & $>0.29$ & $<=3.58$ & $>3.58$ & $<=0.05$ & $>0.05$ \\
\hline 1 & 5.7 & 4.4 & 89.9 & 1.3 & 51.5 & 47.1 & 0.0 & 100.0 & 62.1 & 37.9 \\
\hline 2 & 20.3 & 5.9 & 73.7 & 28.0 & 51.7 & 20.3 & 0.8 & 99.2 & 0.8 & 99.2 \\
\hline 3 & 35.8 & 6.2 & 58.0 & 43.2 & 44.4 & 12.3 & 0.0 & 100.0 & 14.8 & 85.2 \\
\hline 4 & 92.9 & 4.4 & 2.8 & 99.6 & 0.4 & 0.0 & 25.0 & 75.0 & 92.5 & 7.5 \\
\hline 5 & 32.9 & 10.6 & 56.5 & 71.7 & 24.2 & 4.1 & 0.9 & 99.1 & 74.2 & 25.8 \\
\hline 6 & 100.0 & 0.0 & 0.0 & 98.1 & 1.9 & 0.0 & 44.2 & 55.8 & 80.8 & 19.2 \\
\hline 7 & 44.0 & 6.4 & 49.5 & 80.7 & 19.3 & 0.0 & 36.7 & 63.3 & 81.7 & 18.3 \\
\hline 8 & 39.0 & 13.0 & 48.1 & 64.3 & 23.4 & 12.3 & 2.6 & 97.4 & 66.2 & 33.8 \\
\hline
\end{tabular}


Appendix A Table 2. YPG thresholds for input variables, percent of each stream type for ten stream types.

\begin{tabular}{|c|c|c|c|c|c|c|c|c|c|c|c|c|c|}
\hline \multirow{2}{*}{$\begin{array}{c}\text { Stream } \\
\text { Type }\end{array}$} & \multicolumn{2}{|c|}{ Flow Perm (\%) } & \multicolumn{3}{|c|}{$\operatorname{Qp25}\left(\mathrm{m}^{3} / \mathrm{s}\right)$} & \multicolumn{4}{|c|}{ RSI } & \multicolumn{4}{|c|}{ Width $2 \mathrm{~m}(\mathrm{~m})$} \\
\hline & $<=3.32$ & $>3.32$ & $<=208.10$ & $<=354.06$ & $>354.06$ & $<=0.16$ & $<=0.17$ & $<=0.18$ & $>0.18$ & $<=226.10$ & $<=230.04$ & $<=266.46$ & $>266.46$ \\
\hline 1 & 100.0 & 0.0 & 99.4 & 0.3 & 0.3 & 47.7 & 48.0 & 3.7 & 0.7 & 70.9 & 1.9 & 7.7 & 18.9 \\
\hline 2 & 100.0 & 0.0 & 97.2 & 2.4 & 0.4 & 83.3 & 16.6 & 0.1 & 0.0 & 5.5 & 0.3 & 5.6 & 87.9 \\
\hline 3 & 0.0 & 100.0 & 80.0 & 20.0 & 0.0 & 68.0 & 0.0 & 32.0 & 0.0 & 44.0 & 4.0 & 8.0 & 44.0 \\
\hline 4 & 100.0 & 0.0 & 16.1 & 75.0 & 8.9 & 40.1 & 46.9 & 13.0 & 0.0 & 31.8 & 2.6 & 16.7 & 49.0 \\
\hline 5 & 100.0 & 0.0 & 1.9 & 10.7 & 87.4 & 27.7 & 27.7 & 29.6 & 15.1 & 13.8 & 0.0 & 9.4 & 76.1 \\
\hline 6 & 100.0 & 0.0 & 99.7 & 0.3 & 0.0 & 77.1 & 20.8 & 1.8 & 0.3 & 88.5 & 0.8 & 3.1 & 7.0 \\
\hline 7 & 100.0 & 0.0 & 94.4 & 5.0 & 0.6 & 38.8 & 24.4 & 14.4 & 22.5 & 99.4 & 0.0 & 0.0 & 0.0 \\
\hline 8 & 100.0 & 0.0 & 100.0 & 0.0 & 0.0 & 0.0 & 9.4 & 51.9 & 38.7 & 96.6 & 0.4 & 1.7 & 1.3 \\
\hline 9 & 100.0 & 0.0 & 94.5 & 5.5 & 0.0 & 0.0 & 7.4 & 73.3 & 19.4 & 46.5 & 0.9 & 7.4 & 43.3 \\
\hline 10 & 100.0 & 0.0 & 100.0 & 0.0 & 0.0 & 0.0 & 0.0 & 4.5 & 95.5 & 100.0 & 0.0 & 0.0 & 0.0 \\
\hline
\end{tabular}

\begin{tabular}{|c|c|c|c|c|c|c|c|c|c|c|}
\hline \multirow{2}{*}{$\begin{array}{c}\text { Stream } \\
\text { Type }\end{array}$} & \multicolumn{5}{|c|}{ RENDVI Mean } & \multicolumn{5}{|c|}{ Vegetation Cover (\%) } \\
\hline & $<=0.11$ & $<=0.12$ & $<=0.13$ & $<=0.15$ & $>0.15$ & $<=0.23$ & $<=0.23$ & $<=0.46$ & $<=0.51$ & $>0.51$ \\
\hline 1 & 50.0 & 33.0 & 12.0 & 4.8 & 0.1 & 85.8 & 1.0 & 13.0 & 0.1 & 0.0 \\
\hline 2 & 5.3 & 20.3 & 36.1 & 34.2 & 4.0 & 86.7 & 1.3 & 11.4 & 0.3 & 0.3 \\
\hline 3 & 0.0 & 20.0 & 16.0 & 56.0 & 8.0 & 24.0 & 4.0 & 64.0 & 8.0 & 0.0 \\
\hline 4 & 26.0 & 30.7 & 21.9 & 19.8 & 1.6 & 63.5 & 2.6 & 28.1 & 1.6 & 4.2 \\
\hline 5 & 17.6 & 14.5 & 22.0 & 39.0 & 6.9 & 64.2 & 1.9 & 28.3 & 1.3 & 4.4 \\
\hline 6 & 3.1 & 19.0 & 29.2 & 40.9 & 7.8 & 22.7 & 7.3 & 65.1 & 3.1 & 1.8 \\
\hline 7 & 35.0 & 27.5 & 13.1 & 16.9 & 7.5 & 5.6 & 0.6 & 43.8 & 14.4 & 35.6 \\
\hline 8 & 80.4 & 17.9 & 1.7 & 0.0 & 0.0 & 64.3 & 1.3 & 30.6 & 1.7 & 2.1 \\
\hline 9 & 0.0 & 9.2 & 16.6 & 51.6 & 22.6 & 59.4 & 1.8 & 35.5 & 2.8 & 0.5 \\
\hline 10 & 3.6 & 2.7 & 18.0 & 70.3 & 5.4 & 92.8 & 1.8 & 5.4 & 0.0 & 0.0 \\
\hline
\end{tabular}

\begin{tabular}{|c|c|c|c|c|c|c|c|c|c|c|}
\hline \multirow{2}{*}{$\begin{array}{c}\text { Stream } \\
\text { Type }\end{array}$} & \multicolumn{6}{|c|}{ Elevation $(\mathrm{m})$} & \multicolumn{4}{|c|}{ Slope (\%) } \\
\hline & $<=207.65$ & $<=236.65$ & $<=237.23$ & $<=349.33$ & $<=400.63$ & $>400.63$ & $<=3.25$ & $<=4.82$ & $<=17.88$ & $>17.88$ \\
\hline 1 & 51.8 & 14.0 & 0.6 & 32.0 & 1.3 & 0.3 & 93.0 & 4.7 & 2.3 & 0.0 \\
\hline 2 & 66.5 & 11.1 & 0.4 & 16.6 & 2.2 & 3.1 & 100.0 & 0.0 & 0.0 & 0.0 \\
\hline 3 & 56.0 & 8.0 & 0.0 & 4.0 & 20.0 & 12.0 & 96.0 & 4.0 & 0.0 & 0.0 \\
\hline 4 & 46.9 & 14.6 & 0.5 & 36.5 & 1.6 & 0.0 & 99.5 & 0.5 & 0.0 & 0.0 \\
\hline 5 & 40.3 & 10.1 & 0.0 & 35.2 & 7.5 & 6.9 & 96.9 & 1.3 & 1.9 & 0.0 \\
\hline 6 & 4.2 & 7.6 & 0.3 & 41.9 & 16.7 & 29.4 & 96.9 & 3.1 & 0.0 & 0.0 \\
\hline 7 & 5.0 & 6.9 & 0.0 & 41.3 & 15.6 & 31.3 & 83.1 & 16.9 & 40.0 & 0.0 \\
\hline 8 & 12.3 & 12.8 & 0.0 & 44.7 & 21.7 & 8.5 & 86.8 & 12.3 & 0.9 & 0.0 \\
\hline 9 & 0.0 & 0.0 & 0.0 & 51.2 & 36.9 & 12.0 & 97.7 & 1.8 & 0.5 & 0.0 \\
\hline 10 & 0.0 & 0.0 & 0.0 & 39.6 & 30.6 & 29.7 & 78.4 & 21.6 & 27.0 & 7.2 \\
\hline
\end{tabular}

\begin{tabular}{|c|c|c|c|c|c|c|c|c|c|c|c|}
\hline \multirow{2}{*}{$\begin{array}{c}\text { Stream } \\
\text { Type }\end{array}$} & \multicolumn{2}{|c|}{ ER $3 \mathrm{~m} / 05 \mathrm{~m}$} & \multicolumn{4}{|c|}{ Watershed Area $\left(\mathrm{m}^{2}\right)$} & \multicolumn{4}{c|}{ SVRI } \\
\cline { 2 - 11 } & $<=3.55$ & $>3.55$ & $<=31429012$ & $<=103478288$ & $<=358500096$ & $>358500096$ & $<=-0.83$ & $<=0.28$ & $<=0.42$ & $<=0.83$ & $>0.83$ \\
\hline 1 & 26.0 & 74.0 & 97.5 & 2.0 & 0.4 & 0.0 & 72.2 & 27.5 & 0.0 & 0.3 & 0.0 \\
\hline 2 & 62.5 & 37.5 & 81.5 & 16.4 & 1.9 & 0.1 & 38.5 & 54.5 & 1.2 & 2.7 & 3.1 \\
\hline 3 & 44.0 & 56.0 & 60.0 & 24.0 & 12.0 & 4.0 & 8.0 & 68.0 & 0.0 & 16.0 & 8.0 \\
\hline 4 & 38.5 & 61.5 & 15.1 & 60.4 & 24.5 & 0.0 & 46.4 & 45.8 & 3.6 & 3.1 & 1.0 \\
\hline 5 & 67.3 & 32.7 & 1.3 & 18.9 & 58.5 & 21.4 & 38.4 & 57.2 & 0.6 & 2.5 & 1.3 \\
\hline 6 & 16.1 & 83.9 & 98.7 & 1.3 & 0.0 & 0.0 & 15.9 & 66.4 & 5.5 & 10.4 & 1.8 \\
\hline 7 & 63.8 & 36.3 & 98.8 & 1.3 & 0.0 & 0.0 & 20.6 & 46.9 & 13.8 & 11.9 & 6.9 \\
\hline 8 & 23.0 & 77.0 & 100.0 & 0.0 & 0.0 & 0.0 & 31.1 & 68.1 & 0.9 & 0.0 & 0.0 \\
\hline 9 & 47.5 & 52.5 & 84.8 & 15.2 & 0.0 & 0.0 & 38.2 & 60.8 & 0.0 & 0.5 & 0.5 \\
\hline 10 & 48.6 & 51.4 & 100.0 & 0.0 & 0.0 & 0.0 & 0.9 & 58.6 & 8.1 & 19.8 & 12.6 \\
\hline
\end{tabular}


Appendix A Table 3. Fort Huachuca thresholds for input variables and percent of each stream type for eight stream types.

\begin{tabular}{|c|c|c|c|c|c|c|c|c|c|}
\hline \multirow{2}{*}{$\begin{array}{c}\text { Stream } \\
\text { Type }\end{array}$} & \multicolumn{5}{|c|}{ Peak Flow 25-yr 1- $\mathrm{hr}\left(\mathrm{m}^{3} / \mathrm{s}\right)$} & \multicolumn{2}{|c|}{ Vegetation 0 - 1 m (\%) } & \multicolumn{2}{|c|}{ Vegetation 4 - $12 \mathrm{~m}$ (\%) } \\
\hline & $<=112.07$ & $<=262.24$ & $<=350.71$ & $<=785.56$ & $>785.56$ & $<=66.98$ & $>66.98$ & $<=2.54$ & $>2.54$ \\
\hline 1 & 12.5 & 45.8 & 20.8 & 20.8 & 0.0 & 100.0 & 0.0 & 0.0 & 100.0 \\
\hline 2 & 93.1 & 6.9 & 0.0 & 0.0 & 0.0 & 75.9 & 24.1 & 6.9 & 93.1 \\
\hline 3 & 0.0 & 0.0 & 0.0 & 16.7 & 83.3 & 16.7 & 83.3 & 33.3 & 66.7 \\
\hline 4 & 0.0 & 6.5 & 6.5 & 87.1 & 0.0 & 3.2 & 96.8 & 83.9 & 16.1 \\
\hline 5 & 75.0 & 25.0 & 0.0 & 0.0 & 0.0 & 4.2 & 95.8 & 8.3 & 91.7 \\
\hline 6 & 81.4 & 18.6 & 0.0 & 0.0 & 0.0 & 0.0 & 100.0 & 95.3 & 4.7 \\
\hline 7 & 97.3 & 2.7 & 0.0 & 0.0 & 0.0 & 0.0 & 100.0 & 81.1 & 18.9 \\
\hline 8 & 88.7 & 11.3 & 0.0 & 0.0 & 0.0 & 0.0 & 100.0 & 98.4 & 1.6 \\
\hline
\end{tabular}

\begin{tabular}{|c|c|c|c|c|c|c|c|c|}
\hline \multirow{2}{*}{$\begin{array}{c}\text { Stream } \\
\text { Type }\end{array}$} & \multicolumn{2}{|c|}{ Elevation (m) } & \multicolumn{2}{|c|}{$\mathrm{ER} 3 \mathrm{~m} / 0.5 \mathrm{~m}$} & \multicolumn{2}{|c|}{ Width $2 \mathrm{~m}(\mathrm{~m})$} & \multicolumn{2}{|c|}{ Flow Permanence (\%) } \\
\hline & $<=1423.65$ & $>1423.65$ & $<=9.15$ & $>9.15$ & $<=90.8$ & $>90.8$ & $<=26.32$ & $>26.32$ \\
\hline 1 & 0.0 & 100.0 & 100.0 & 0.0 & 100.0 & 0.0 & 8.3 & 91.7 \\
\hline 2 & 0.0 & 100.0 & 100.0 & 0.0 & 100.0 & 0.0 & 44.8 & 55.2 \\
\hline 3 & 0.0 & 100.0 & 0.0 & 100.0 & 83.3 & 16.7 & 16.7 & 83.3 \\
\hline 4 & 74.2 & 25.8 & 83.9 & 16.1 & 51.6 & 48.4 & 48.4 & 51.6 \\
\hline 5 & 4.2 & 95.8 & 95.8 & 4.2 & 100.0 & 0.0 & 16.7 & 83.3 \\
\hline 6 & 44.2 & 55.8 & 48.8 & 51.2 & 44.2 & 55.8 & 74.4 & 25.6 \\
\hline 7 & 100.0 & 0.0 & 100.0 & 0.0 & 67.6 & 32.4 & 100.0 & 0.0 \\
\hline 8 & 75.8 & 24.2 & 95.2 & 4.8 & 79.0 & 21.0 & 93.5 & 6.5 \\
\hline
\end{tabular}


Appendix A Table 4. Fort Bliss thresholds for input variables and percent of each stream type for eight stream types.

\begin{tabular}{|c|c|c|c|c|c|c|c|c|c|c|c|}
\hline \multirow{2}{*}{ Stream Types } & \multicolumn{2}{|c|}{ Flow Perm (\%) } & \multicolumn{4}{|c|}{ Peak Flow Qp25 (m3/s) } & \multicolumn{2}{|c|}{ Veg <0.5 m (\%) } & \multicolumn{3}{|c|}{ Veg 1-4m (\%) } \\
\hline & $<=14.16$ & $>14.16$ & $<=317.35$ & $<=438.91$ & $<=544.30$ & $>544.30$ & $<=82.93$ & $>82.93$ & $<=12.75$ & $<=20.11$ & $>20.11$ \\
\hline 1 & 99.1 & 0.9 & 97.3 & 1.8 & 0.9 & 0.0 & 99.1 & 0.9 & 3.6 & 5.5 & 90.9 \\
\hline 2 & 100.0 & 0.0 & 96.6 & 2.7 & 0.7 & 0.0 & 99.3 & 0.7 & 60.3 & 30.8 & 8.9 \\
\hline 3 & 1.5 & 98.5 & 74.6 & 0.0 & 3.0 & 22.4 & 50.7 & 49.3 & 67.2 & 9.0 & 23.9 \\
\hline 4 & 100.0 & 0.0 & 98.7 & 1.3 & 0.0 & 0.0 & 4.8 & 95.2 & 100.0 & 0.0 & 0.0 \\
\hline 5 & 100.0 & 0.0 & 100.0 & 0.0 & 0.0 & 0.0 & 0.0 & 100.0 & 100.0 & 0.0 & 0.0 \\
\hline 6 & 100.0 & 0.0 & 98.0 & 1.7 & 0.4 & 0.0 & 10.2 & 89.8 & 99.8 & 0.2 & 0.0 \\
\hline 7 & 100.0 & 0.0 & 87.1 & 7.3 & 3.8 & 1.8 & 2.8 & 97.2 & 100.0 & 0.0 & 0.0 \\
\hline 8 & 100.0 & 0.0 & 5.3 & 3.0 & 9.1 & 82.6 & 13.6 & 86.4 & 97.7 & 2.3 & 0.0 \\
\hline
\end{tabular}

\begin{tabular}{|c|c|c|c|c|c|c|c|c|c|c|}
\hline \multirow{2}{*}{ Stream Types } & \multicolumn{4}{|c|}{ RENDVI Mean (vegetation density) } & \multicolumn{3}{|c|}{ RSI } & \multicolumn{3}{|c|}{ Width $2 \mathrm{~m}(\mathrm{~m})$} \\
\hline & $<=0.15$ & $<=0.16$ & $<=0.19$ & $>0.19$ & $<=0.19$ & $<=0.22$ & $>0.22$ & $<=162.42$ & $<=188.99$ & $>188.99$ \\
\hline 1 & 0.9 & 2.7 & 26.4 & 70.0 & 41.8 & 30.0 & 28.2 & 99.1 & 0.0 & 0.9 \\
\hline 2 & 12.3 & 14.4 & 37.0 & 36.3 & 56.8 & 43.2 & 0.0 & 100.0 & 0.0 & 0.0 \\
\hline 3 & 4.5 & 7.5 & 35.8 & 52.2 & 32.8 & 67.2 & 0.0 & 77.6 & 3.0 & 19.4 \\
\hline 4 & 3.8 & 7.2 & 54.4 & 34.6 & 6.4 & 85.0 & 8.6 & 76.4 & 7.2 & 16.4 \\
\hline 5 & 90.0 & 6.5 & 3.5 & 0.0 & 30.0 & 70.0 & 0.0 & 88.3 & 8.3 & 3.5 \\
\hline 6 & 56.4 & 20.0 & 22.7 & 0.9 & 42.5 & 57.1 & 0.4 & 87.6 & 5.9 & 6.5 \\
\hline 7 & 89.1 & 9.1 & 1.8 & 0.0 & 15.7 & 84.3 & 0.0 & 9.4 & 8.9 & 81.8 \\
\hline 8 & 37.1 & 11.4 & 34.1 & 17.4 & 28.8 & 69.7 & 1.5 & 34.8 & 7.6 & 57.6 \\
\hline
\end{tabular}

\begin{tabular}{|c|c|c|c|c|c|c|c|c|c|c|c|}
\hline \multirow{2}{*}{ Stream Types } & \multicolumn{2}{|c|}{ ER $3 \mathrm{~m} / 05 \mathrm{~m}$} & \multicolumn{6}{|c|}{ Percent Slope (\%) } & \multicolumn{3}{|c|}{ Veg 4-12m (\%) } \\
\hline & $<=6.43$ & $>6.43$ & $<=2.85$ & $<=3.07$ & $<=8.56$ & $<=11.07$ & $<=23.72$ & $>23.72$ & $<=1.11$ & $<=4.52$ & $>4.52$ \\
\hline 1 & 100.0 & 0.0 & 1.8 & 0.0 & 51.8 & 7.3 & 25.5 & 13.6 & 8.2 & 13.6 & 78.2 \\
\hline 2 & 99.3 & 0.7 & 1.4 & 7.5 & 71.2 & 10.3 & 9.6 & 0.0 & 66.4 & 30.1 & 3.4 \\
\hline 3 & 95.5 & 4.5 & 34.3 & 3.0 & 46.3 & 4.5 & 9.0 & 3.0 & 68.7 & 11.9 & 19.4 \\
\hline 4 & 95.4 & 4.6 & 47.7 & 6.7 & 37.3 & 5.1 & 3.2 & 0.0 & 99.7 & 0.3 & 0.0 \\
\hline 5 & 100.0 & 0.0 & 62.6 & 6.5 & 30.9 & 0.0 & 0.0 & 0.0 & 100.0 & 0.0 & 0.0 \\
\hline 6 & 90.9 & 9.1 & 34.8 & 4.4 & 53.6 & 3.1 & 4.1 & 0.0 & 99.8 & 0.2 & 0.0 \\
\hline 7 & 96.2 & 3.8 & 94.9 & 2.0 & 3.0 & 0.0 & 0.0 & 0.0 & 100.0 & 0.0 & 0.0 \\
\hline 8 & 85.6 & 14.4 & 68.9 & 5.3 & 23.5 & 0.0 & 2.3 & 0.0 & 97.7 & 1.5 & 0.8 \\
\hline
\end{tabular}

\begin{tabular}{|c|c|c|c|c|c|c|c|c|c|}
\hline \multirow{2}{*}{ Stream Types } & \multicolumn{2}{|c|}{ Veg $0.5-1 \mathrm{~m}(\%)$} & \multicolumn{2}{|c|}{ Watershed Area (m2) } & \multicolumn{3}{|c|}{ Elevation (m) } & \multicolumn{2}{|c|}{ Veg. Cover (\%) } \\
\hline & $<=3.23$ & $>3.23$ & $<=164494480$ & $>164494480$ & $<=1404.74$ & $<=1466.43$ & $>1466.43$ & $<=51.65$ & $>51.65$ \\
\hline 1 & 2.7 & 97.3 & 100.0 & 0.0 & 0.9 & 1.8 & 97.3 & 2.7 & 97.3 \\
\hline 2 & 0.7 & 99.3 & 100.0 & 0.0 & 11.0 & 10.3 & 78.8 & 42.5 & 57.5 \\
\hline 3 & 25.4 & 74.6 & 91.0 & 9.0 & 3.0 & 3.0 & 94.0 & 44.8 & 55.2 \\
\hline 4 & 62.5 & 37.5 & 100.0 & 0.0 & 8.3 & 6.4 & 85.3 & 50.7 & 49.3 \\
\hline 5 & 95.7 & 4.3 & 100.0 & 0.0 & 0.9 & 10.0 & 89.1 & 100.0 & 0.0 \\
\hline 6 & 17.4 & 82.6 & 100.0 & 0.0 & 43.8 & 26.6 & 29.6 & 97.0 & 3.0 \\
\hline 7 & 75.2 & 24.8 & 100.0 & 0.0 & 65.6 & 9.6 & 24.8 & 100.0 & 0.0 \\
\hline 8 & 47.0 & 53.0 & 77.3 & 22.7 & 40.9 & 20.5 & 38.6 & 81.1 & 18.9 \\
\hline
\end{tabular}




\section{Appendix B. AGWA Model Uncertainty}

The Automated Geospatial Watershed Assessment (AGWA) tool is mainly designed to provide qualitative estimates of runoff and erosion for use as a relative change tool for scenario analysis; however, with careful model calibration using high quality observations of precipitation and streamflow data, it can provide quantitative estimates as well. To run either the KINEROS2 or SWAT model the user employs the AGWA interface in ArcMap (ESRI, 2010) to delineate the watershed boundary from a chosen outlet based on a digital elevation dataset. The watershed is then discretized into smaller hydrologic response units for SWAT (HRUs), or overland and channel model elements for KINEROS2 that are parameterized by intersecting soil, landcover and precipitation data. AGWA creates the required input files for the selected model, and displays the results in tabular, hydrograph, and map form.

In this research, AGWA was used with the KINEROS2 model to develop values for peak flow, and with the SWAT model for flow permanence. Yatheendradas et al. (2008) identified rainfall estimates (depth/volume estimates and spatiotemporal resolution), model parameters, and initial soil moisture conditions as uncertainty sources in the KINEROS2 model. Hernandez et al. (2000) looked at both KINEROS2 and SWAT and found that the curve number, saturated hydraulic conductivity, and the spatial variability of rainfall, affected model performance. However, because of the extremely large and diverse study area for this project (approx. $10,770 \mathrm{~km}^{2}$; 2,661,000 acres) field measurements for most of the parameters were not feasible. Precipitation and streamflow data were also generally not available except for a portion of Fort Huachuca. To improve model performance and address those uncertainty sources, SWAT was calibrated to the extent possible at Fort Huachuca, and those parameter modifications were applied at the three other installations.

No sensitivity analyses were conducted for the KINEROS2 model for this project; however, Goodrich et al. (1991; 1994) and Yatheendradas et al. (2008) investigated the effect of initial soil water content on runoff simulations at the Walnut Gulch Experimental Watershed, and suggested that the spatial variation of rainfall in small watersheds (i.e. approximately $0.04 \mathrm{~km}^{2}$ ) has a larger effect on runoff characteristics than initial soil moisture. For medium sized watersheds (i.e. approximately $6.3 \mathrm{~km}^{2}$ ) results indicated that a single basin average for initial soil moisture did not seriously limit runoff simulations. Simulated watersheds for this project varied in size from $0.28 \mathrm{~km}^{2}$ to $1368 \mathrm{~km}^{2}$. Walnut Gulch has an average annual precipitation of approximately 312 mm (Goodrich et al., 2008), and all streams are ephemeral. The default values were used for all variables in the KINEROS2 simulations.

KINEROS2 is an event-based model and does not compute inter-storm soil moisture conditions. This information is provided as an initial condition, and defaults to 0.2 initial soil water content or saturation index, SI (Goodrich, 1990). This value can be modified by the user, but was left at the default value for this project because the model uses design storms instead of observed data. Holding soil moisture constant in this way allowed us to compare relative differences across stream reaches, and produce the stream type classification and methodology. In these waterlimited environments soil moisture tends to be very low except immediately following a precipitation event. The saturation index, $\mathrm{SI}=0.20$ is an approximate median initial pre-storm soil moisture condition based on CREAMS (Knisel et al., 1980) daily water balance simulations 
at 11 rain gauges within the USDA-ARS Walnut Gulch Experimental Watershed in southeastern Arizona over approximately 50 rainfall events. An option would have been to bracket the KINEROS2 simulations using an SI of $\sim 0.1$ for dry conditions, and SI of $\sim 0.5$ for wet conditions, but that option was not employed.

For the SWAT model, soil moisture is addressed as part of the Curve Number (CN) which is a function of the hydrologic group, hydrologic condition, cover type and antecedent soil moisture for average basin wetness; CN is adjusted on a daily time step (Miller et al., 2002). Soil hydrologic group is obtained from soils data, and cover type is from classified land cover data. These datasets provide a conservative estimate for our study sites given their arid to semi-arid climate regimes. Lyon (2013) calibrated SWAT for peak flow at Fort Huachuca using USGS stream flow gauge data. Fort Huachuca is the only one of our study sites with gauge data that could be used to calibrate the model. Lyon (2013) found that to match observed peak flow amounts, the Curve Number must be decreased by 15\%, in addition to other adjustments to input values. This indicated that the default assumptions in AGWA over-estimated the amount of moisture in the soil, which resulted in an over-estimation of the amount of runoff. The sensitivity analysis conducted for the SWAT simulations showed that the Curve Number (CN) was one of the most important input variables in the model. SWAT assumes antecedent moisture condition II (average basin wetness) for calculation of the Curve Number, and adjusts CN on a daily time step based on modeled soil moisture.

Precipitation is another important input to these models, and the stream type classification results indicated the importance of the local rainfall regimes. In arid and semiarid environments the additional water gathered by drainage systems is critical for supporting riparian systems. Numerous studies (Stromberg et al., 1991; Lite et al., 2005; Stromberg et al., 2007; Levick et al., 2008) have shown that riparian type and condition are correlated to streamflow amount and magnitude. In turn, streamflow characteristics can be significantly influenced by disturbance and climate. Because of the high degree of spatiotemporal variability in rainfall and runoff in the southwest, and the lack of actual measurement data in these regions (only a thinly scattered network of rain gauges and very few stream gauges exist), various data sources were evaluated to identify the most appropriate rainfall data. Fort Huachuca had the best network of rain gauges, and USGS stream flow gauges at Upper Garden (USGS 09470800) and Huachuca (USGS 09471310) Canyons that allowed for model calibration to improve accuracy. Thus, Fort Huachuca was used as the test case to determine if nationally available climate datasets were suitable for use in the models for all installations included in this study.

SWAT requires average daily precipitation values for several years as input, and KINEROS2 requires design storm data. At Fort Huachuca, daily precipitation data were obtained from seven meteorological stations (met stations) located within the installation boundary, and from the National Climatic Data Center's (NCDC) TD3200 U.S. Cooperative Summary of Day dataset (https://www.ncdc.noaa.gov/data-access/land-based-station-data/land-baseddatasets/cooperative-observer-network-coop) for all gauges located in or near Fort Huachuca. The models were run with both precipitation datasets. Simulations in Garden Canyon showed an average difference in surface flow of less than $4 \%$, suggesting that precipitation data from the NCDC datasets could be used for model inputs at the other installations (Fort Irwin, YPG, and Fort Bliss) where local rain gauge data are unavailable or sparse. Further analysis of the NCDC 
and met station data showed that the model failed to pick up some storms, suggesting that the low resolution of rain gauges was not capturing the spatial variability typical of convective summer storms in the area. This led to the use of the finer resolution $\left(4 \mathrm{~km}^{2}\right)$ NEXRAD-MPE radar data to provide improved representation of the spatial variability of summer convective storms than the sparse NCDC rain gauge network. To confirm that the NEXRAD data were acceptable for input to SWAT, a statistical comparison was performed on the model outputs at Fort Huachuca using the NCDC rain gauge data, the met tower data, and the NEXRAD data. The model was calibrated at both the Upper Garden Canyon and Huachuca Canyon stream flow gauges, using each precipitation input for a subset of years and validated using the remaining data. Both SWAT-NEXRAD and SWAT-rain gauge simulations obtained acceptable levels of accuracy based on $\mathrm{R}^{2}$ and NSE values for average monthly totals during both calibration and validation time periods. The similarity between rain gauge and radar results observed at Upper Garden and Huachuca Canyons suggested that the NEXRAD-MPE data can serve as an accurate substitute for field observations where rain gauges are absent or possibly achieve better results where they are scarce (for more details, see Lyon, 2013). These data were used as precipitation input at all four installations.

KINEROS2 was used to obtain peak flow for a variety of storm durations and return intervals for each HRU in the study areas. KINEROS2 requires precipitation frequency estimates for specific return intervals and durations. Estimates of these values were acquired at each watershed center from NOAA’s National Weather Service Hydrometeorological Design Studies Center Precipitation Frequency Data Server (NOAA PFDS, 2012; http://hdsc.nws.noaa.gov/hdsc/pfds/index.html). The PFDS allows for the input of geographical coordinates of each watershed center to determine precipitation depths based on a frequency analysis of partial duration series. Design storms were created from the PFDS data using the centroid coordinate for each watershed in the study areas. Applying a design storm created from a single point estimate across an entire watershed tends to result in an overestimation of runoff due to the failure to account for spatial heterogeneity of the input data (Miller et al., 2002). To account for discrepancies an aerial reduction factor was applied to the depth values based on Osborn et al. (1980) and expanded in NOAA's Technical Memorandum NWS HYDRO-40 (Zehr and Myers, 1984) to average the depths over the entire watershed. Peak flows for the 5-, 10-, 25and 100-yr 1-hr storms were applied on all watersheds at all four installations. 


\section{Literature Cited}

Arnold, J.G., Williams, J. R., Srinivasan, R., King, K.W. and Griggs, R. H. 1994. SWAT-Soil Water Assessment Tool. USDA, Agricultural Research Service, Grassland, Soil and Water Research Laboratory, Temple, Texas. http://swat.tamu.edu/

Aviad, B., and Roy, G. 2011. Classification by clustering decision tree-like classifier based on adjusted clusters. Expert Systems with Applications, 38:8220-8228. https://doi.org/10.1016/j.eswa.2011.01.001

Benton, J., Ripley, J.D., and Powledge, F., eds. 2008. Conserving Biodiversity on Military Lands: A Guide for Natural Resources Managers. 2008 edition. Available at http://www.dodbiodiversity.org. Arlington, Virginia: NatureServe.

Breiman, L., Friedman, J.H., Olshen, R.A. and Stone, C.J. 1984. Classification and Regression Trees. Wadsworth and Brooks Publishing, Monterey, California. ISBN 0412048418, 9780412048418

Bull, L.J. and Kirkby, M.J. 2002. Dryland river characteristics and concepts. In: Dryland Rivers: Hydrology and Geomorphology of Semi-Arid Channels. L.J. Bull and M.J. Kirkby (eds.), John Wiley \& Sons Ltd., Chichester, England. p. 3-15.

Cable, D.R. 1969. Competition in the Semidesert Grass-shrub Type as Influenced by Root Systems, Growth Habits, and Soil Moisture Extraction. Ecology, 50(1); 27-38. https://doi.org/10.2307/1934659

Canadell, J., Jackson, R.B., Ehleringer, J.R., Mooney, H.A., Sala, O.E., Schulze, E.D. 1996. Maximum Rooting Depth of Vegetation Types at the Global Scale. Oecologia, 108(4); 583-595. http://www.jstor.org/stable/4221458

Carlson, E.A. 2009. Fluvial Riparian Classifications for National Forests in the Western United States. M.S. Thesis. Colorado State University, Fort Collins, CO; 194 pp. https://www.fs.fed.us/biology/nsaec/assets/carlson_thesis_version_11.pdf

Curtis, K.E., Lichvar, R.W., Dixon, L.E. 2011. Ordinary High Flows and the Stage-Discharge Relationship in the Arid West Region. ERCD/CRREL TR-11-12. Hanover, NH, US Army Engineer Research and Development Center, Cold Regions Research and Engineering Laboratory. http://www.dtic.mil/dtic/tr/fulltext/u2/a550816.pdf

Dust, D.W. and Wohl, E.E. 2010. Quantitative technique for assessing the geomorphic thresholds for floodplain instability and braiding in the semi-arid environment. Natural Hazards, 55:145-160. https://doi.org/10.1007/s11069-010-9553-2

Elagib, N.A. 2011. Changing Rainfall Seasonality and Erosivity in the Hyper-Arid Zone of Sudan. Land Degradation \& Development, 22(6):505-512. https://doi.org/10.1002/ldr.1023

ESRI. 2010. ArcGIS Desktop: Redlands, CA: Environmental Systems Research Institute.

Gibbens, R.P. and Lenz, J.M. 2001. Root systems of some Chihuahuan Desert Plants. Journal of Arid Environments, 49: 221-263. https://doi.org/10.1006/jare.2000.0784

Goodrich, D.C. 1990. Geometric simplification of a distributed rainfall-runoff model over a range of basin scales. PhD Dissertation, Univ. of Arizona, Tucson. http://hdl.handle.net/10150/185051

Goodrich, D.C., Bach, L.B., Weltz, M.A., Jackson, T.J., Schmugge, T.J., Keefer, T.O., Amer, S.A., Unkrich, C.L. 1991. Preliminary runoff simulation sensitivity to various measures of soil water content. Tenth Conference on Biometeorology and Aerobiology and the 
Special Sessions on Hydrometeorology, Sept. 10-13, 1991, Salt Lake City, Utah. https://www.tucson.ars.ag.gov/unit/publications/PDFfiles/868.pdf

Goodrich, D.C., Schmugge, T.J., Jackson, T.J., Unkrich, C.L, Keefer, T.O., Parry, R., Bach, L.B, Amer, S.A. 1994. Runoff simulation sensitivity to remotely sensed initial soil water content. Water Resources Research, 30(5): 1393-1405. https://doi.org/10.1029/93WR03083

Goodrich, D.C., Keefer, T.O., Unkrich, C.L., Nichols, M.H., Osborn, H.B., Stone, J.J., Smith, J.R. 2008. Long-term precipitation database, Walnut Gulch Experimental Watershed, Arizona, United States. Water Resources Research, 44. https://doi.org/10.1029/2006WR005782

Goodrich, D.C., Burns, I.S., Unkrich, C.L., Semmens, D., Guertin, D.P., Hernandez, M., Yatheendradas, S., Kennedy, J.R., Levick, L. 2012. KINEROS2/AGWA: Model Use, Calibration, and Validation. Transactions of the ASABE. 55(4): 1561-1574. https://www.tucson.ars.ag.gov/unit/publications/PDFfiles/2175.pdf

Gothai, E. and Balasubramanie, P. 2012. An Efficient Way for Clustering Using Alternative Decision Tree. American Journal of Applied Sciences, 9(4):531-534. http://thescipub.com/PDF/ajassp.2012.531.534.pdf

Graf, W.L. 1988. Fluvial Processes in Dryland Rivers. Springer-Verlag, New York. p. 346

Gungle, B., United States. Bureau of Land Management \& Geological Survey (U.S.). 2006. Timing and duration of flow in ephemeral streams of the Sierra Vista Subwatershed of the upper San Pedro basin, Cochise County, southeastern Arizona. USGS Scientific Investigations Report 2005-5190. https://pubs.usgs.gov/sir/2005/5190/

Hammer, S. 2014. Ephemeral and intermittent streams as wildlife habitat at Fort Bliss, New Mexico/Texas. M.S. thesis. University of Arizona, Tucson, AZ.

Hernandez, M., Miller, S.N., Goodrich, D.C., Goff, B.F., Kepner, W.G., Edmonds, C.M., Jones, K.B. 2000. Modeling runoff response to land cover and rainfall spatial variability in semi-arid watersheds. Environmental Monitoring and Assessment, 64(1): 285-298. https://doi.org/10.1023/A:1006445811859

Kennard, M.J., Pusey, B.J., Olden, J.D., Mackay, S.J., Stein, J.L. and Marsh, N. 2010. Classification of natural flow regimes in Australia to support environmental flow management. Freshwater Biology, 55:171-193. https://doi.org/10.1002/rra.1249

Kirkby, M.J., Gallart, F., Kjeldsen, T.R., Irvine, B.J., Froebrich, J., Lo Porto, A., De Girolamo, A., and the MIRAGE Team. 2011. Classifying low flow hydrological regimes at a regional scale. Hydrology and Earth System Sciences, 15(12), 3741-3750. https://doi.org/10.5194/hess-15-3741-2011

Knisel, W. G. (Editor), 1980. CREAMS: A Field Scale Model for Chemicals, Runoff, and Erosion from Agricultural Management Systems, U.S. Department of Agriculture, Science and Education Administration, Conservation Research Report, 26, 643 p.

Levick, L., Fonseca, J., Goodrich, D., Hernandez, M., Semmens, D., Stromberg, J., Leidy, R., Scianni, M., Guertin, D.P., Tluczek, M., and Kepner, W. 2008. The Ecological and Hydrological Significance of Ephemeral and Intermittent Streams in the Arid and Semiarid American Southwest. U.S. Environmental Protection Agency and USDA/ARS Southwest Watershed Research Center. EPA/600/R-08/134, ARS/233046, 116 pp. https://www.epa.gov/sites/production/files/201503/documents/ephemeral_streams_report_final_508-kepner.pdf 
Levick, L., Hammer, S., Lyon, R., Murray, J., Birtwistle, A., Goodrich, D., Bledsoe, B., Guertin, P., Laituri, M. 2015. An Ecohydrological Approach to Managing Intermittent and Ephemeral Streams on Department of Defense Lands in the Southwestern United States. Dept. of Defense Strategic Environmental Research and Development Program, Project RC-1727 (www.serdp-estcp.org). https://serdp-estcp.org/Program-Areas/ResourceConservation-and-Resiliency/Natural-Resources/Arid-Lands-Ecology-andManagement/RC-1727

Lite, S.J., K.J. Bagstan, and J.C. Stromberg. 2005. Riparian plant species richness along lateral and longitudinal gradients of water stress and flood disturbance, San Pedro River, Arizona, USA. Journal of Arid Environments 63(4): 785-813. https://doi.org/10.1016/j.jaridenv.2005.03.026

Lopez-Bermudez, F., Conesa-Garcia, C, Alonso-Sarria, A. 2002. Floods: Magnitude and Frequency in Ephemeral Stream of the Spanish Mediterranean Region. In: Dryland Rivers: Hydrology and Geomorphology of Semi-Arid Channels. L.J. Bull and M.J. Kirkby (eds.), John Wiley \& Sons Ltd., Chichester, England. P. 329-350.

Lyon, R. 2013. Using rainfall-runoff models to characterize the flow regime of desert streams in the U.S. southwest. M.S. Thesis, University of Arizona, Tucson.

McManamay, R.A., Bevelhimer, M.S., Kao, SC. 2013. Updating the US Hydrologic Classification: An Approach to Clustering and Stratifying Ecohydrologic Data. Ecohydrology, 7:903-926. https://doi.org/10.1002/eco.1410

Miller, S.N., Semmens, D.J., Hernandez, M., Goodrich, D.C., Miller, W.P., Kepner, W.G., Ebert, D. 2002. GIS-based hydrologic modeling: the Automated Geospatial Watershed Assessment tool. In: Proceeding of the Second Federal Interagency Hydrologic Modeling Conference, July 28 - August 1, 2002, Las Vegas NV, CD-ROM, 12 p.

Miller, S.N., Semmens, D.J., Goodrich, D.C., Hernandez, M., Miller, R.C., Kepner, W.G. and Guertin, D.P. 2007. The Automated Geospatial Watershed Assessment Tool. J. Environmental Modeling \& Software, 22:365.377. https://doi.org/10.1016/j.envsoft.2005.12.004

Milligan, G.W. and Cooper, M.C. 1985. An Examination of Procedures for Determining the Number of Clusters in a Data Set. Psychometrika. 50(2):159.179. https://doiorg.ezproxy4.library.arizona.edu/10.1007/BF02294245

Montgomery, D.R., and Buffington, J.M. 1997. Channel-reach morphology in mountain drainage basins. GSA Bulletin, v.109(5):596-611.

NatureServe. 2014. NatureServe Explorer: An online encyclopedia of life [web application]. Version 7.1. NatureServe, Arlington, Virginia. Available http://explorer.natureserve.org

NOAA. 2012. National Oceanic and Atmospheric Administration's Precipitation Frequency Data Server. Precipitation dataset. Retrieved 04/25/2012, from http://dipper.nws.noaa.gov/hdsc/pfds/

O’Connor C.D., Sheppard, B.S., Falk, D.A. and Garfin. G.G. 2016. Quantifying post-fire flooding risk associated with changing climate at Fort Huachuca, Arizona. Report of Project RC-2232 to the US Department of Defense Strategic Environmental Research and Development Program (SERDP). 32pp.

Olden, J.D., Lawler, J.J., Poff, N.L. 2008. Machine Learning Methods Without Tears: A Primer for Ecologists. The Quarterly Review of Biology, 83(2):171-193. http://www.jstor.org.ezproxy4.library.arizona.edu/stable/10.1086/587826 
Omernik, J.M. and Griffith, G.E. 2014. Ecoregions of the Conterminous United States: Evolution of a Hierarchical Spatial Framework. Environmental Management 54:1249-1266. https://doi.org/10.1007/s00267-014-0364-1

Osborn, H. B., Lane, L. J., Myers, V. A. 1980. Rainfall-Watershed Relationships for Southwestern Thunderstorms. Transactions of the ASAE, 23(1):82. https://elibrary.asabe.org/azdez.asp?AID $=34529 \& \mathrm{t}=2$

Oueslati, O., De Girolamo, A.M., Abouabdillah, A., Kjeldsen, T.R., and Porto, A.L. 2015. Classifying the flow regimes of Mediterranean streams using multivariate analysis. Hydrological Processes, 29:4666-4682. https://doi.org/10.1002/hyp.10530

PRISM Climate Group. 2010. Oregon State University, http://prism.oregonstate.edu

Qi, J., Chehbouni, A., Huete, A.R., Kerr, Y.H., Sorooshian, S. 1994. A Modified Soil Adjusted Vegetation Index. Remote Sensing of Environment, 48:119-126. https://doi.org/10.1016/0034-4257(94)90134-1

R Core Team (2014). R: A language and environment for statistical computing. R Foundation for Statistical Computing, Vienna, Austria. http://www.R-project.org

Rosgen, D. 1994. A Classification of Natural Rivers. Catena, 22(3): 169-199. https://doi.org/10.1016/0341-8162(94)90001-9

Rubinoff, J., Wills, T., Sekscienski, S. and Belfit, S. 2006. Installation Summaries from the FY2006 Survey of Threatened and Endangered Species on Army Lands. U.S. Army Environmental Command Aberdeen Proving Ground, Maryland.

Salford Systems, SPM. 2004. RandomForests; An Implementation of Leo Breiman's RF, by Salford Systems. http://salford-systems.com

Sharma, H. and Kaler N.K. 2013. Data Mining with Improved and Efficient Mechanism in Clustering Analysis and Decision Tree as a Hybrid Approach. International Journal of Innovative Technology and Exploring Engineering (IJITEE), 2(5):58-60. https://www.ijitee.org/download/volume-2-issue-5/

Stromberg, J.C., Pattern, D.T. and Richter, B.D. 1991. Flood flows and dynamics of Sonoran riparian forests. Rivers 2(3): 221-235. https://asu.pure.elsevier.com/en/publications/floodflows-and-dynamics-of-sonoran-riparian-forests

Stromberg, J.C., Beauchamp, V.B., Dixon, M.D., Lite, S.J. and Paradzick, C. 2007. Importance of low-flow and high-flow characteristics to restoration of riparian vegetation along rivers in arid south-western United States. Freshwater Biology 52(4): 651-679. https://doi.org/10.1111/j.1365-2427.2006.01713.x

Stromberg, J.C., Gallo, E.L., Lohse, K.A., Meixner, T., Moody, E.K., Sabo, J.L. and Setaro D.L. 2015. Structure and Function of Ephemeral Streams in the Arid and Semiarid Southwest: Implications for Conservation and Management. DOD-SERDP Project RC-1726. https://serdp-estcp.org/Program-Areas/Resource-Conservation-and-Resiliency/NaturalResources/Arid-Lands-Ecology-and-Management/RC-1726

U.S. Geological Survey (USGS). 2006. National Hydrography Dataset (NHD) website, http://nhd.usgs.gov/index.html.

Weichelt, H., Rosso, P., Marx, A., Reigber, S., Douglass, K., Heynen, M. 2012. The RapidEye Red Edge Band White Paper. Accessed Nov. 26, 2012 https://resa.blackbridge.com/files/2014-06/Red_Edge_White_Paper.pdf

Woolhiser, D.A., Smith, R.E. and Goodrich D.C. 1990. KINEROS, A Kinematic Runoff and Erosion Model: Documentation and User Manual. U.S. Department of Agriculture, 
Agricultural Research Service, ARS-77, 130 pp.

https://www.tucson.ars.ag.gov/unit/Publications/PDFfiles/703.pdf

Yatheendradas, S., Wagener, T., Gupta, H., Unkrich, C., Goodrich, D., Schaffner, M., and

Stewart, A. 2008. Understanding uncertainty in distributed flash flood forecasting for

semiarid regions. Water Resources Research, vol. 44.

https://doi.org/10.1029/2007WR005940

Zehr, R. M., Myers, V. A., and United States National Weather Service. 1984. Depth-area ratios in the semi-arid southwest United States. Vol. 40 of NOAA technical memorandum NWS HYDRO. U.S. Dept. of Commerce, National Oceanic and Atmospheric Administration, National Weather Service.

https://babel.hathitrust.org/cgi/pt?id=uiug.30112102558738;view=1up;seq=3 